$1-1-2012$

\title{
Affordable Care Act Litigation: The Standing Paradox
}

Elizabeth Weeks Leonard

University of Georgia Main Campus, weeksleo@uga.edu

Depress

\section{Repository Citation}

Elizabeth Weeks Leonard, Affordable Care Act Litigation: The Standing Paradox (2012),

Available at: https://digitalcommons.law.uga.edu/fac_artchop/900

This Article is brought to you for free and open access by the Faculty Scholarship at Digital Commons @ University of Georgia School of Law. It has been accepted for inclusion in Scholarly Works by an authorized administrator of Digital Commons @ University of Georgia School of Law. Please share how you have benefited from this access For more information, please contact tstriepe@uga.edu. 


\title{
Affordable Care Act Litigation: The Standing Paradox
}

\author{
Elizabeth Weeks Leonard ${ }^{\dagger}$
}

\section{INTRODUCTION}

The Patient Protection and Affordable Care Act (ACA or the "Act") litigation presents a standing paradox. In the current posture, it appears that states lack standing to challenge the federal law on behalf of individuals, while individuals possess standing to challenge the federal law on behalf of states. This Article contends that there is no principled reason for this asymmetry and argues that standing doctrine should apply as liberally to states as to individuals, assuming states allege the constitutional minimum requirements for standing and especially where the legal challenge turns on the allocation of power between the federal government and the states. While states may have no greater claim to judicial review of federal laws than individuals, they should not have any less. ${ }^{1}$

\section{A. Procedural Posture of the aCA litigation}

The Supreme Court will not have to reach this particular procedural conundrum to decide the merits of the Florida lawsuit on which it granted certiorari ${ }^{2}$ because the particular constellation of plaintiffs before the Court covers all fronts. The two substantive claims are, first, whether the ACA's minimum essential coverage requirement, popularly known as the individual mandate, exceeds Congress's

\footnotetext{
${ }^{\dagger}$ Associate Professor, University of Georgia School of Law. Special thanks to Abigail Moncrieff for both hosting the Symposium and providing valuable suggestions for improving this Article. Earlier drafts also benefited immeasurably from comments by Dan Coenen, Brendan Maher, Lou Mulligan, Jack Preis, Neil Siegel, and Mike Wells.

${ }^{1}$ This contention is both broader and less qualified than previous commentators' suggestions. See, e.g., Robert A. Schapiro, Judicial Federalism and the Challenges of State Constitutional Contestation, 115 PENN. ST. L. REV. 983, 1005 (2011) (expressing concern with judicial decisions granting states "a special pass into court" or granting "special solicitude" to state standing, and concluding, "[p]erhaps states deserve no less judicial protection than other parties, but they do not seem to need more"); Ann Woolhandler \& Michael G. Collins, State Standing, 81 VA. L. REV. 387, 519 (1995) (limiting state standing to challenge federal legislation to situations in which states' interests are primarily threatened and denying state standing "when individuals are the more immediate objects of such regulation").

${ }^{2}$ See Nat'l Fed'n of Indep. Bus. v. Sebelius, 132 S. Ct. 603 (2011) (mem.); Dep't of Health \& Human Servs. v. Florida, 132 S. Ct. 604 (2011) (No. 11-398) (mem.) (argued Mar. 26-27, 2012); Florida v. Dep't of Health \& Human Servs., 132 S. Ct. 604 (2011) (No. 11-400) (mem.) (argued Mar. 28, 2012).
} 
enumerated commerce or spending powers, ${ }^{3}$ and, second, whether the ACA's expansion of Medicaid eligibility to low-income, non-elderly adults exceeds previously articulated limits on Congress's conditional spending power to encourage state cooperation in implementing federal programs. ${ }^{4}$ Plaintiffs in the Florida lawsuit include two small business owners, the National Federation of Independent Business (NFIB), and twenty-six states. ${ }^{5}$ The individual business owners allege that the ACA's minimum essential coverage requirement has already caused them injury-infact ${ }^{6}$ by compelling them to alter their business and financial practices in anticipation of the individual mandate's 2014 effective date. ${ }^{7}$ Even if one or both of the individual plaintiffs falls out of the lawsuit, ${ }^{8}$ the NFIB would likely maintain standing to represent the interests of its individual members. ${ }^{9}$ Alternatively, there are many other similarly affected individuals and small business owners who could join the suit, alleging personal injury. ${ }^{10}$

The states challenge both the individual mandate and Medicaid expansion. States clearly have standing on the Medicaid claim as that issue alleges federal coercion or commandeering of states and state officials in violation of the Tenth Amendment. ${ }^{11}$ Medicaid expansion operates directly on states, imposing new federal requirements on the states themselves. ${ }^{12}$ States' standing to challenge the individual mandate is murkier, however. The individual mandate, by its terms, applies to

${ }^{3}$ Dep't of Health \& Human Servs., 132 S. Ct. 604; see 26 U.S.C.A. $\$ 5000$ A(a)-(b) (West 2012) (requiring that all "applicable individuals" (1) shall maintain "minimum essential coverage" for themselves and their dependents, or (2) pay a monetary penalty).

${ }^{4}$ Florida, 132 S. Ct. 604; see 42 U.S.C.A. $\S 1396$ a(a)(10)(A)(i)(VIII) (West 2012) (extending Medicaid eligibility to adults under age sixty-five, who are not pregnant and not already covered, with incomes up to $133 \%$ of the federal poverty level); South Dakota v. Dole, 483 U.S. 203, 207-08 (1987) (listing limits on conditional spending power).

${ }^{5}$ Florida ex rel. Att'y Gen. v. U.S. Dep't of Health \& Human Servs., 648 F.3d 1235 (11th Cir. 2011 ), cert. granted sub nom. Nat'l Fed'n of Indep. Bus., 132 S. Ct. 603, and cert. granted sub nom. Dep't of Health \& Human Servs., 132 S. Ct. 604, and cert. granted in part sub nom., Florida, $132 \mathrm{~S}$. Ct. 604

${ }^{6}$ U.S. CONST. art. III, $\S 2$ (limiting federal courts' jurisdiction to "cases" and "controversies"); Lujan v. Defenders of Wildlife, 504 U.S. 555, 560-61 (1992) (listing three requirements for standing, including "injury in fact").

7 Florida ex rel. Bondi v. Dep't of Health \& Human Servs., 780 F. Supp. 2d 1256, 1270-71 (N.D. Fla.), order clarified, 780 F. Supp. $2 \mathrm{~d} 1307$ (N.D. Fla.), aff'd in part, rev'd in part, 648 F.3d 1235 (11th Cir. 2011), cert. granted sub nom. Nat'l Fed'n of Indep. Bus. v. Sebelius, 132 S. Ct. 603 (2011) (mem.), and cert. granted, 132 S. Ct. 604 (2011) (No. 11-398) (mem.) (argued Mar. 26-27, 2012), and cert. granted in part, 132 S. Ct. 604 (2011) (No. 11-400) (mem.) (argued Mar. 28, 2012).

Jess Bravin \& Vanessa O'Connell, Business Owner's Bankruptcy Disclosed to Supreme Court, WALL. ST. J., Dec. 19, 2011, http://online.wsj.com/article/SB10001424052970204879004 $577108951415171134 . \mathrm{html}$ (discussing changed circumstances of one plaintiff, which might impact her standing to bring a challenge to the individual mandate).

${ }^{9}$ See Hunt v. Wash. Apple Adver. Comm'n, $432^{\circ}$ U.S. 333, 342-43 (1977) (regarding requirements of association standing)

${ }^{10}$ See Orders in Pending Cases, Nat'l Fed'n of Indep. Bus., 132 S. Ct. 603, Dep't of Health \& Human Servs., 132 S. Ct. 604, Florida, 132 S. Ct. 604 (U.S. Jan. 17, 2012), available at http://www.supremecourt.gov/orders/courtorders\%5C011712zor.pdf (granting NFIB's motion to add additional individual petitioners and respondents to the litigation); Jess Bravin \& Emily Maltby, Health-Law Opponents Try to Add Plaintiffs to Lawsuit, WALL ST. J., Jan. 5, 2012, http://online.wsj.com/article/SB10001424052970204331304577141072540030502.html.

"See Brief of State Petitioners on Medicaid at 21-22, Dep't of Health \& Human Servs. (No. 11 400) (U.S. Jan. 10, 2012), 2012 WL 105551, available at http://aca-litigation.wikispaces.com/ file/view/States+brief+as+petitioner+\%28Medicaid\%29.pdf (summary of argument).

${ }^{12}$ See, e.g., New York v. United States, 505 U.S. 144 (1992) (regarding disposal of radioactive waste); South Dakota v. Dole, 483 U.S. 203 (1987) (involving minimum drinking age). 
individuals, not states. ${ }^{13}$ It is enacted under federal law, carries a federal tax penalty for non-compliance, and will be enforced by federal authorities. ${ }^{14}$ States have offered various theories of standing to challenge the individual mandate, but the Court likely will not have to resolve that question. ${ }^{15}$ As long as one individual plaintiff or the association representing individuals in the Florida case retains standing, the question of the constitutionality of the individual mandate is properly before the Court. ${ }^{16}$

Lower courts' decisions in the ACA litigation, however, leave the standing paradox unresolved. At least one court wrote strongly that a state, suing alone, may not challenge the individual mandate. ${ }^{17}$ That decision may be the product of strategic error by the plaintiff-state or the court's restrictive application of standing doctrine. By contrast, lower court decisions, described in detail below, liberally allowed individuals to challenge the individual mandate's constitutionality-not as a violation of their own individual rights but as an intrusion on states' reserved powers-as long as the plaintiffs alleged concrete, particularized injury. ${ }^{18}$ After cataloguing courts' treatment of individual plaintiffs' standing claims, this Article contends that courts should similarly allow states to challenge the scope of federal power, as long as states meet the same constitutional requirements for standing.

\section{B. STANDING DOCTRINE}

The essential contours of federal standing law are well established and not at issue in the ACA litigation. Article III of the U.S. Constitution limits federal judicial power to the adjudication of cases or controversies. ${ }^{19}$ The case-or-controversy requirement means that the plaintiff must have standing to bring a challenge. ${ }^{20}$ The "irreducible constitutional minimum of standing" consists of three elements:

${ }^{13}$ One statutory role for states with respect to the individual mandate is tied to health insurance exchanges, which are required to certify individuals as exempt from the individual mandate. Patient Protection and Affordable Care Act (PPACA), Pub. L. No. 111-148, § 1311(d)(4), 124 Stat. 119 (2010) (to be codified primarily in scattered sections of 42 U.S.C.). Accordingly, if states elect to operate their own exchanges, rather than leaving that task to the federal government, they would be required to perform that certification function.

${ }^{14} 26$ U.S.C.A. $\$ 5000 \mathrm{~A}(\mathrm{c})$ (West 2012 ) (providing federal income tax penalty); id. $\S 5000 \mathrm{~A}(\mathrm{~g})$ (specifying federal enforcement).

${ }^{15}$ See Florida ex rel. Att'y Gen. v. Dep't of Health \& Human Servs., 648 F.3d 1235, 1243 (11th Cir. 2011), cert. granted sub nom. Nat'l Fed'n of Indep. Bus. v. Sebelius, 132 S. Ct. 603 (2011) (mem.), and cert. granted, 132 S. Ct. 604 (2011) (No. 11-398) (mem.) (argued Mar. 26-27, 2012), and cert. granted in part, 132 S. Ct. 604 (2011) (No. 11-400) (mem.) (argued Mar. 28, 2012) (noting that "the question of the state plaintiffs" standing to challenge the individual mandate is an interesting and difficult one, in the posture of this case, it is purely academic and one we need not confront today").

${ }^{16} \mathrm{Id}$. (noting that "[t]he law is abundantly clear that so long as at least one plaintiff has standing to raise each claim-as is the case here-we need not address whether the remaining plaintiffs have standing" and citing cases); see also Rumsfeld v. Forum for Academic \& Institutional Rights, Inc., 547 U.S. $47,52 \mathrm{n} .2$ (2006) (noting that only one of the petitioners needs to have standing to permit the Court to consider the petition for review).

${ }^{17}$ See Virginia ex rel. Cuccinelli v. Sebelius, 656 F.3d 253, 272 (4th Cir. 2011), petition for cert. filed, 80 U.S.L.W. 3221 (U.S. Sept. 30, 2011) (No. 11-420).

${ }^{18}$ See infra Part III (summarizing lower court decisions).

${ }^{19}$ U.S. CONST. art. III, $\S 2$; Flast v. Cohen, 392 U.S. 83, $95-96$ (1968).

${ }^{20}$ Elk Grove Unified Sch. Dist. v. Newdow, 542 U.S. 1, $11-12$ (2004). 
First, the plaintiff must have suffered an "injury in fact"-an invasion of a legally protected interest which is (a) concrete and particularized,... and (b) "actual or imminent, not 'conjectural' or "hypothetical"'.... Second, there must be a causal connection between the injury and the conduct complained of - the injury has to be "fairly . . . trace[able] to the challenged action of the defendant, and not ... th [e] result [of] the independent action of some third party not before the court." .. . Third, it must be "likely," as opposed to merely "speculative," that the injury will be "redressed by a favorable decision." 21

A plaintiff may allege either actual present injury or imminent future injury. ${ }^{22}$ With respect to associations, the Supreme Court held that

an association has standing to bring suit on behalf of its members when: (a) its members would otherwise have standing to sue in their own right; (b) the interests it seeks to protect are germane to the organization's purpose; and (c) neither the claim asserted nor the relief requested requires the participation of individual members in the lawsuit. $^{23}$

The Court has interpreted the "concrete and particularized" injury requirement to mean that generalized grievances about the government, "claiming only harm to [the plaintiff's] and every citizen's interest in proper application of the Constitution and laws," do not support Article III standing. "While it does not matter how many persons have been injured by the challenged action, the party bringing suit must show that the action injures him in a concrete and personal way." 25 The fact that an injury may be widely shared, or that a political forum may also be available to raise the issue, does not lessen the injury or necessarily deprive the court of jurisdiction. ${ }^{26}$

The constitutional requirements for standing "preserve[] the vitality of the adversarial process" by assuring that the parties before the Court have a real stake in the outcome and that the issues will be resolved "not in the rarified atmosphere of a debating society, but in a concrete, factual context." "More important, the law of Article III standing is built on a single basic idea-the idea of separation of powers." 28 The separation of powers doctrine limits the role of courts, committing certain subject matter to Congress and the political process. "In significant part, a

\footnotetext{
${ }^{21}$ Lujan v. Defenders of Wildlife, 504 U.S. 555, 560-61 (1992) (citations omitted) (internal quotation marks omitted).

${ }^{22}$ Id. at 560 .

${ }^{23}$ Hunt v. Wash. State Apple Adver. Comm'n, 432 U.S. 333, 343 (1977).

${ }^{24}$ Lujan, 504 U.S. at 573-74.

${ }^{25} \mathrm{Id}$. at 581 (Kennedy, J., concurring).

${ }^{26}$ See FEC v. Atkins, 524 U.S. 11, 24-25 (1998); Public Citizen v. U.S. Dep't of Justice, 491 U.S. $440,449-50$ (1989).

${ }^{27}$ Lujan, 504 U.S. at 581 (Kennedy, J., concurring); see Valley Forge Christian Coll. v. Ams. United for Separation of Church \& State, Inc., 454 U.S. 464, 472 (1982).

${ }^{28}$ Allen v. Wright, 468 U.S. 737, 752 (1984); see generally Antonin Scalia, The Doctrine of Standing as an Essential Element of the Separation of Powers, 17 SUFFOLK U. L. REV. 881 (1983) (explaining that standing is an integral part of the separation of powers doctrine).

${ }^{29}$ See United States v. Richardson, 418 U.S. 166, 179 (1974) ("Lack of standing within the narrow confines of Art. III jurisdiction does not impair the right to assert his views in the political forum or at the polls. Slow, cumbersome, and unresponsive though the traditional electoral process may be thought at times, our system provides for changing members of the political branches when
} 
debate over what constitutes 'injury in fact' sufficient for Article III is thus a debate about separation of powers and the respective responsibilities of Congress and the Court." ${ }^{30}$ Justiciability limits, including standing, also "empower the executive branch to promote its policies, constrained by political, rather than judicial limits." 31 By channeling only disputes that satisfy the constitutional minimum requirements, the standing doctrine respects "the proper-and properly limited-role of the courts in a democratic society." 32

\section{INDIVIDUAL AND STATE CHALLENGES TO THE ACA}

In the ACA litigation, both states and individuals are suing the federal government or representatives in their official capacity, challenging the constitutionality of ACA. Typically, constitutional litigation involves individuals or private entities suing government defendants. Until relatively recently, states rarely sued the federal government to vindicate their own or their citizens' rights. ${ }^{33}$ Conflicts over the relative power of states and the federal government were resolved through the political, not judicial, process. ${ }^{34}$ These structural issues might end up in court if individuals seek to defend themselves from federal enforcement actions by challenging the applicable law as exceeding Congress's enumerated powers. ${ }^{35}$ In the ACA litigation, the individual claims arise in just that posture. States also challenge certain ACA provisions, however, defending the contours of state power under the Constitution and, perhaps derivatively, the rights of individual state inhabitants.

dissatisfied citizens convince a sufficient number of their fellow electors that elected representatives are delinquent in performing duties committed to them.").

${ }^{30}$ William A. Fletcher, The Structure of Standing, 98 YALE L.J. 221, 233 (1988).

${ }^{31}$ See Allen, 468 U.S. at 761 (noting that separation of powers principle "counsels against recognizing standing in a case brought, not to enforce specific legal obligations whose violation works a direct harm, but to seek a restructuring of the apparatus established by the Executive Branch to fulfill its legal duties. The Constitution, after all, assigns to the Executive Branch, and not to the Judicial Branch, the duty to 'take Care that the Laws be faithfully executed. . . We could not recognize respondents' standing in this case without running afoul of that structural principle.") (internal citation omitted); Schapiro, supra note 1, at 985 (citing sources).

${ }^{32}$ See Allen, 486 U.S. at 750 (quoting Warth v. Seldin, 422 U.S. 490,498 (1975)).

${ }^{33}$ See Massachusetts v. Envtl. Prot. Agency, 549 U.S. 497, 518 (2007) ("Well before the creation of the modern administrative state, we recognized that States are not normal litigants for the purposes of invoking federal jurisdiction."); see also Schapiro, supra note 1, at 986; Woolhandler \& Collins, supra note 1 , at 390 .

${ }^{34}$ See Garcia v. San Antonio Metro. Transit Auth., 469 U.S. 528, 552 (1985) (noting "effectiveness of the federal political process in preserving the States' interests"); Herbert Wechsler, The Political Safeguards of Federalism: The Role of the States in the Composition and Selection of the National Government, 54 CoLUM. L. REV. 543, 558 (1954) ("[T] he national political process in the United States-and especially the role of the states in the composition and selection of the central government-is intrinsically well adapted to retarding or restraining new intrusions by the center on the domain of the states."); see also Jesse H. Choper, The Scope of National Powers Vis-à-Vis the States: The Dispensability of Judicial Review, 86 YALE L.J. 1552, 1557 (1977) (arguing that the national political system protects states' interests in Congress and that the federal courts should focus on individual rights); Schapiro, supra note 1, at 983 (noting that "states may actively oppose national policy" through political means).

${ }_{35}$ Schapiro, supra note 1, at 988; Woolhander \& Collins, supra note 1, at 439-40; see supra note 34 (listing examples). 


\section{A. INDIVIDUALS LITIGATING STATES' INTERESTS}

Private parties suing over the ACA include individuals, subject to the minimum essential coverage requirement, ${ }^{36}$ or employers, subject to the employer responsibility provisions. ${ }^{37}$ In both cases, the plaintiffs challenge the federal government's enforcement of tax penalties on them for failing to comply with the applicable provisions. Lacking cognizable due process, equal protection, or other individual right claims ${ }^{38}$ the lawsuits assert that the ACA is an unconstitutional exercise of congressional power and, therefore, the Act, or at least the challenged provisions, cannot be applied against them.

To be sure, there are plausible individual rights objections to the requirement to purchase health insurance, including interference with autonomous healthcare decision-making and freedom of contract. At the core, the objections sound in libertarian rights and economic liberty to be free from government coercion. Opponents contend that the federal government cannot require individuals to purchase a good or service from another private individual or company. Arguments asserting rights to bodily autonomy or freedom to make healthcare decisions are unavailing because the mandate does not require individuals to receive any particular medical treatment, or, indeed, any treatment at all. Nor does it require individuals to seek medical care under the health insurance policies that they purchase; it merely requires the purchase of health insurance. ${ }^{39}$

Individual rights claims, while politically salient and arguably sympathetic, likely would not support the plaintiffs' arguments to strike down the individual mandate as unconstitutional. In the Court's post-Lochner era, ${ }^{40}$ economic liberties do not receive robust protection, and government intrusions on them are subject only to low-level judicial scrutiny. ${ }^{41}$ The individual mandate likely would survive such scrutiny. ${ }^{42}$ The congressional record amply demonstrates various flaws in healthcare

${ }^{36} 26$ U.S.C.A. $\S 5000 \mathrm{~A}$ (West 2012).

${ }^{37} \mathrm{Id}$ \& $4980 \mathrm{H}$.

${ }^{38}$ See Mark A. Hall, The Constitutionality of Mandates to Purchase Health Insurance, 37 J.L. MED. \& ETHICS 40, 44-47 (2009) (considering individual rights claims); Abigail R. Moncrieff, Safeguarding the Safeguards: The ACA Litigation and the Extension of Structural Protection to NonFundamental Liberties, 64 FLA. L. REV. (forthcoming 2012) (manuscript at 4-5), available at http://papers.ssrn.com/sol3/papers.cfm?abstract_id=1919272 (explaining "that, in most scholars" view, the individual mandate simply does not infringe liberty - at least not in any constitutionally meaningful way" and considering and dismissing various other arguments).

39 In fact, the risk-pooling objective of the individual mandate is served all the better if individuals purchase, but do not use, health insurance. The individual mandate aims to redistribute the cost of insurance among high-risk and low-risk individuals by requiring everyone to purchase a policy. Premiums paid by low-risk individuals who purchase insurance but do not use their coverage will subsidize high-risk individuals whose medical costs exceed their premium contributions.

${ }^{40}$ Lochner v. New York, 198 U.S. 45 (1905), overruled by W. Coast Hotel Co. v. Parish, 300 U.S. 379, 391 (1937) ("What is this freedom? The Constitution does not speak of freedom of contract.").

${ }^{41}$ See Erwin Chemerinsky, A Defense of the Constitutionality of the Individual Mandate, 62 MERCER L. REV. 618, 618 (2011) ("The Supreme Court has made it clear in terms of due process that the government can regulate the economy so long as it has a rational basis for doing so."); Richard E. Levy, Escaping Lochner's Shadow: Towards a Coherent Jurisprudence of Economic Rights, 73 N.C. L. REV. 329, 344-45 (1995) (noting that since 1937, the Court routinely applies "the deferential rational basis test" to economic liberty claims and that "[u]nder this test, the government need only show that a measure is reasonably related to some conceivable legitimate purpose").

${ }^{42}$ See Thomas More Law Ctr. v. Obama, 651 F.3d 529, 544-45 (6th Cir. 2011), petition for cert. filed, (U.S. July 26, 2011) (No. 11-117) (reasoning that Congress had a rational basis for the individual mandate). 
markets and adverse selection problems presented if Congress does not couple the ACA's popular provisions banning pre-existing condition exclusions ${ }^{43}$ and guaranteeing issuance ${ }^{44}$ and renewability ${ }^{45}$ of policies with a mandate to purchase insurance before individuals become ill. ${ }^{46} \mathrm{With}$ individual rights claims unavailing, opponents of the mandate instead assert structural arguments regarding the scope of federal enumerated powers as compared to states' reserved powers.

But it is not immediately apparent what interest private individuals and entities have in maintaining the federalist structure of government. One way of framing their interest is that the very purpose of diffusing power between a central government and separate sovereign states is to protect individual rights; hence, structural issues necessarily are individual rights issues. Affirming that view of federalism, a recent Supreme Court decision in Bond v. United States ${ }^{47}$ recognized an individual's standing to challenge enforcement of a federal statute, not on the basis of a particular federal enumerated power, but squarely on states' Tenth Amendment reserved powers. Justice Kennedy, writing for the majority, noted "an individual has a direct interest in objecting to laws that upset the constitutional balance between the National Government and the States when the enforcement of those laws causes injury that is concrete, particular, and redressable. Fidelity to principles of federalism is not for the States alone to vindicate."48 Although involving a very different statute and very different sort of injury, Bond does establish precedent for individuals to bring constitutional claims based on states' rights, effectively invigorating the Tenth Amendment as an individually cognizable claim. ${ }^{49}$

Another way of thinking about individual plaintiffs' interests in vindicating states' rights is the potential for state recognition of broader individual liberties than federal law. The U.S. Constitution establishes a floor, requiring states to recognize at least that level of individual rights, but states may exceed the federal floor and accord even greater protection. ${ }^{50}$ For example, even though the Federal Constitution,

${ }^{43} 42$ U.S.C.A. $\S 300 \mathrm{gg}-3$ (West 2012).

${ }^{44} I d . \S 300 \mathrm{gg}-1(\mathrm{a})$.

${ }^{45} \mathrm{Id} . \S 300 \mathrm{gg}-2(\mathrm{~b})$.

${ }^{46}$ Florida ex rel. Attorney Gen. v. Dep't of Health \& Human Servs., 648 F.3d 1235, 1244-48 (11th Cir. 2011), cert. granted sub nom. Nat'l Fed'n of Indep. Bus. v. Sebelius, 132 S. Ct. 603 (2011) (mem.), and cert. granted, 132 S. Ct. 604 (2011) (No. 11-398) (mem.) (argued Mar. 26-27, 2012), and cert. granted in part, 132 S. Ct. 604 (2011) (No. 11-400) (mem.) (argued Mar. 28, 2012) (summarizing congressional findings regarding healthcare and health insurance systems); Thomas More, 651 F.3d at 544-45 (citing congressional record and other sources).

${ }^{47} 131$ S. Ct. 2355, 2358 (2011) (challenging conviction under 18 U.S.C. $\S 229$, which forbids knowing possession or use, for nonpeaceful purposes, of a chemical that "can cause death, temporary incapacitation or permanent harm to humans").

${ }^{48} I d$. at 2364.

${ }^{49}$ See Garrett Epps, U.S. v. Bond: Reexamining the Mysterious lOth Amendment, THE ATLANTIC (Feb. 18, 2011, 4:03 PM), http://www.theatlantic.com/national/archive/2011/02/us-v-bondreexamining-the-mysterious-10th-amendment/71436/ (suggesting that the case offers "oblique hints about how the Justices are thinking about the pending health-care challenge"); Frank Minter, Did the Supreme Court Tip Its Hand on ObamaCare?, AM. THINKER (June 23, 2011), http://www.americanthinker.com/201 1/06/did_the_supreme_court_tip_its_hand_on_obamacare.html (quoting Justice Kennedy's question during the $\bar{B}$ ond argument and suggesting it foreshadows "how he might rule on ObamaCare"). But see Adam Liptak, Court Weighs the Power of Congress, N.Y. TIMES, Feb. 22, 2011, http://www.nytimes.com/2011/02/23/us/politics/23scotus.html (suggesting that unique facts of Bond "offer[s] only limited guidance on the health care law's prospects").

${ }^{50}$ See Akhil Reed Amar, Five Views of Federalism: "Converse 1983" in Context, 47 VAND. L. REv. 1229, 1244 (2004) ("[T]he federal Constitution ... establishes a minimum baseline-a floorthat state judges must respect on penalty of reversal. But the floor need not become a ceiling."). 
post-Lochner, does not robustly protect economic liberties, state law could. Accordingly, states might enact statutes or constitutional amendments shielding their own residents from a requirement to purchase health insurance, as long as federal law did not provide otherwise. ${ }^{51}$ That suggestion sounds in the new federalism scholarship, ${ }^{52}$ which "share[s] the ultimate goal of creating in every state a vigorous, independent body of state constitutional law." ${ }^{53}$ More broadly, new federalism advocates reinvigorating states' rights and shifting the balance of power back to state governments through judicial and legislative channels. ${ }^{54}$ In this view, private plaintiffs' structural challenges to the individual mandate may derive from an interest in defending or reinvigorating economic liberties under state law.

Allowing individuals to raise structural challenges as defenses to enforcement of federal laws is not novel to the ACA context. ${ }^{55}$ But the strategy has the dramatic effect of elevating individual rights claims from easily overcome rational-relation scrutiny to effectively no scrutiny at all. ${ }^{56}$ If a federal law exceeds enumerated

${ }^{51}$ Timothy S. Jost, Can the States Nullify Health Reform?, 362 NEW ENG. J. MED. 869, 870 (2010) (describing "first-generation" nullification statutes and amendments, which were not aimed at actual federal legislation); see infra notes 94-95 (describing Virginia's and other states' Health Care Freedom Acts). Before ACA, such laws would not be preempted and could have been intended to block state legislators from enacting a state-level individual health insurance mandate, such as Massachusetts did in 2006. See MASS. GEN. L. ch. $111 \mathrm{M}, \S 2$ (2010) ("Duty for certain adults to obtain and maintain creditable coverage.").

${ }^{52}$ See James A. Gardner, The Failed Discourse of State Constitutionalism, 90 MICH. L. REV. 761, $771(1991)$.

s3 Id.; see also Paul W. Kahn, Commentary, Interpretation and Authority in State Constitutionalism, 106 HARV. L. REV. 1147, 1147, 1159 (1993) (noting that state constitutionalism should be free from that of the federal government); Hans A. Linde, First Things First: Rediscovering the States' Bills of Rights, 9 U. BALT. L. REV. 379, 390-91 (1980) (noting the tendency for state law arguments to be undermined).

${ }^{54}$ See, e.g., Jack M. Balkin \& Sanford Levinson, Understanding the Constitutional Revolution, 87 VA. L. REV. 1045, 1052-54 (2001); Erwin Chemerinsky, The Federalism Revolution, 31 N.M. L. REV. 7, 7-8 (2001); Richard L. Hasen, Congressional Power to Renew the Preclearance Provisions of the Voting Rights Act After Tennessee v. Lane, 66 OHIO ST. L.J. 177, 177 (2005) ("As part of [the new federalism] revolution, the Court has greatly restricted the ability of Congress to pass laws regulating the conduct of the states under its enforcement powers granted in Section Five of the Fourteenth Amendment ...."); Jeffrey A. Modisett, Discovering the Impact of the "New Federalism" on State Policy Makers: A State Attorney General's Perspective, 32 IND. L. REV. 141, 141 (1998).

${ }^{55}$ See, e.g., Gonzales v. Raich, 545 U.S. 1 (2005) (Commerce Clause challenge to Federal Controlled Substances Act raised by users and growers of marijuana); United States v. Morrison, 529 U.S. 598 (2000) (Commerce Clause challenge to Federal Violence Against Women Act raised by rape defendants); United States v. Lopez, 514 U.S. 549 (1995) (Commerce Clause challenge to Federal Gun-Free School Zones Act brought by criminal defendant); see also, e.g., Immigration \& Naturalization Serv. v. Chada, 462 U.S. 919 (1983) (alien sought review of deportation order, challenging Federal Immigration and Nationality Act on separation of powers grounds); Pike $v$. Bruce Church, Inc., 397 U.S. 137 (1970) (fruit grower challenged Arizona intrastate packing and processing requirement on dormant Commerce Clause grounds); Hammer v. Dagenhart, 247 U.S. 251 (1918) (hearing father's suit to enjoin enforcement of federal child labor law as violating 10th Amendment), overruled by United States v. Darby, 312 U.S. 100 (1941); Ward v. Maryland, 79 U.S. (12 Wall.) 418 , $426-27,432$ (1871) (invalidating state sales tax on Commerce Clause grounds on individual's challenge).

${ }_{56}^{5}$ See Peter J. Smith, Federalism, Lochner, and the Individual Mandate, 91 B.U. L. REV. 1723, 1746 (2011) (discussing effect of allowing structural federalism challenge to individual mandate would "categorically preclude" Congress from taking certain actions intruding on individual liberty, whereas individual liberty claim would allow Congress to justify the intrusion with "compelling government interests"). 
powers, Congress may not enact it, no matter how good its reasons. ${ }^{57}$ By contrast, a substantive due process, individual rights challenge would at least allow Congress to justify its reasons for infringing on otherwise constitutionally protected rights. In effect, individuals would become independent citizen-enforcers of structural limits of the Constitution, overriding legislative policy judgments. Accepting that individuals may bring political objections to the courts in that posture, it is hard to see sound reasons for denying states the same opportunity.

\section{B. STATES LITIGATING INDIVIDUALS' INTERESTS}

Under ACA, the easy question is states' standing to challenge Medicaid expansion because those new federal requirements operate directly on states. ${ }^{58}$ The hard question is states' standing to challenge the individual mandate, which, by its terms, does not operate on states, but rather on state inhabitants. ${ }^{59}$ The law is well settled that states cannot sue merely as nominal plaintiffs, asserting the rights of their citizens against enforcement of federal laws. But when states claim concrete, particularized injuries to their own rights and interests, courts should recognize state standing. Moreover, there seems to be no harm in further allowing states that have satisfied the constitutional minimum for standing also to litigate their citizens' interests in maintaining limits on federal power.

Under the established Mellon doctrine, states cannot maintain suits merely as representatives of citizens to protect them against unconstitutional congressional acts. ${ }^{60}$ In Massachusetts $v$. Mellon, the Commonwealth of Massachusetts sought to challenge the constitutionality of the Federal Maternity Leave Act, which appropriated federal funds for maternal and child health and gave states the option of cooperating with the federal government's efforts. ${ }^{61}$ Massachusetts had not yet opted into the program but alleged that the federal law invaded its "rights and powers as a sovereign state and the rights of its citizens." ${ }^{62}$ Rejecting the Commonwealth's assertion of standing, the Court first noted that the Maternity Leave Act did not invade state powers because the Constitution does not obligate states to assist the federal government. ${ }^{63}$ The only other burden that the Commonwealth could assert was taxation, which fell upon state inhabitants, not the state itself. ${ }^{64}$ The Court concluded that the Commonwealth could not maintain a suit as a representative of its citizens, noting that states have no "duty or power to enforce their [citizens'] rights in respect of their relations with the federal government. In that field it is the United

${ }^{57} I d$. at $1739-40,1746$ (observing that some collective action problems, such as the difficulty individuals with pre-existing conditions face obtaining insurance, may call for a national solution and that striking down the individual mandate on structural grounds would prevent Congress from addressing those problems, even if states are simply unable). But see Neil S. Siegel, Four Constitutional Limits that the Minimum Coverage Provision Respects, 27 CONST. CommENT. 591, 607-09 (2011) (suggesting that congressional exercise of commerce power to mandate purchase of health insurance could be justified as a collective action problem).

${ }_{58}$ See 42 U.S.C.A. $\S 1396 a(a)(10)(A)(i)(V I I I)$ (West 2012) (listing requirements for state plans to receive federal matching dollars, expanding Medicaid eligibility).

${ }^{59} 26$ U.S.C.A. $\S 5000 \mathrm{~A}$ (a)-(b) (West 2012) (mandating that "an applicable individual" maintain "minimum essential coverage" and providing penalties for noncompliance).

${ }^{60}$ Massachusetts v. Mellon, 262 U.S. 447, 485-86 (1923); see Woolhandler \& Collins, supra note 1 , at $490-92$.

${ }^{61}$ Mellon, 262 U.S. at 479.

${ }^{62} \mathrm{Id}$.

${ }^{63} \mathrm{Id}$. at 480 .

${ }^{64} \mathrm{Id}$. at 482 . 
States, and not the state, which represents them as parens patriae ..." As the Court summarized in a later case: "If the State is only a nominal party without a real interest of its own-then it will not have standing under the parens patriae doctrine.",66

The Court, however, has recognized state standing when proprietary, sovereign, and quasi-sovereign interests are at stake. ${ }^{67}$ First, states may maintain standing to redress injury to their own proprietary interests, such as owning land, streams, and highways, or engaging in business ventures like private proprietors. ${ }^{68}$ Second, states have standing to litigate questions of sovereignty, such as border disputes. ${ }^{69}$ More difficult sovereign standing questions arise over states' governing interests, that is, the exercise of sovereign power "to create and enforce a legal code." If a state claims that its own rights, not merely its citizens' rights, are implicated, the Court may recognize standing. For example, states are allowed to challenge federal laws that purport to apply directly to state governments, ${ }^{71}$ like Medicaid, ${ }^{72}$ or interfere with recognized state regulatory power, such as voting requirements. ${ }^{73}$ In challenging the Federal Voting Rights Act, a state could not, however, assert due process, bill of attainder, or separation of powers arguments, as those rights belonged to citizens, not the states. ${ }^{74}$ The state interest in voting derived from the Constitution's recognition of general state control of election qualifications. ${ }^{75}$

The third category of state standing cases, dubbed "quasi-sovereign interests," involves "interests that the State has in the well-being of its populace." interest, however, must still be sufficiently concrete to create an actual controversy with the defendant. ${ }^{77}$ "[T] $\left.\mathrm{T}\right]$ Se State must articulate an interest apart from the interests of particular private parties - that is, the State must be more than a nominal party." Applying those principles, the Court in Alfred L. Snapp \& Son, Inc. v. Puerto Rico allowed Puerto Rico to bring suit against Virginia apple growers for violating federal law by favoring domestic laborers over foreign temporary laborers. ${ }^{79}$ The Court

\footnotetext{
${ }^{65}$ Id. at 486.

${ }^{66}$ Alfred L. Snapp \& Son v. Puerto Rico, 458 U.S. 592, 600 (1982) (citing cases).

${ }^{67} \mathrm{Id}$. at 600-02 (setting out categories of cases); Schapiro, supra note 1, at $989-93$ (describing same).

${ }^{68}$ See Snapp, 458 U.S. at 601-02; Pennsylvania v. West Virginia, 262 U.S. 553 (1923) (allowing one state to sue another state on its own behalf and as representative of consuming public over state law restricting natural gas pipelines); Schapiro, supra note 1, at 989 (describing states' proprietary interests)

${ }^{69}$ Snapp, 485 U.S. at 601 (regarding "maintenance and recognition of borders"); Woolhandler \& Collins, supra note 1, at 415-16 (summarizing cases).

${ }^{70}$ Snapp, 485 U.S. at 601.

${ }^{71}$ See, e.g., New York v. United States, 505 U.S. 144 (1992); South Dakota v. Dole, 483 U.S. 203 (1987); see also Schapiro, supra note 1, at 990.

${ }^{72}$ See Florida ex rel. Attorney Gen. v. Dep't of Health \& Human Servs., 648 F.3d 1235, 1256-66 (11th Cir. 2011), cert. granted sub nom. Nat'l Fed'n of Indep. Bus. v. Sebelius, 132 S. Ct. 603 (2011) (mem.), and cert. granted, 132 S. Ct. 604 (2011) (No. 11-398) (mem.) (argued Mar. 26-27, 2012), and cert. granted in part, 132 S. Ct. 604 (2011) (No. 11-400) (mem.) (argued Mar. 28, 2012).

${ }^{73}$ See Oregon v. Mitchell, 400 U.S. 112 (1970); South Carolina v. Katzenbach, 383 U.S. 301 (1966); Schapiro, supra note 1, at 990; Woolhandler \& Collins, supra note 1, at $492-93$.

${ }^{74}$ Katzenbach, 383 U.S. at 323-24.

${ }^{75}$ Mitchell, 400 U.S. at 119-25 (citing U.S. CoNST. art. I, $\S 2$, 4, and noting limited federal authority under 15 th Amendment)

${ }^{76}$ Alfred L. Snapp \& Son. v. Puerto Rico, 458 U.S. 592, 602 (1982).

${ }^{77} \mathrm{Id}$.

${ }^{78} \mathrm{Id}$. at 593

${ }^{79} \mathrm{Id}$.
} 
recognized states' "interest in the health and well-being of its residents," beyond mere physical effects of air and water pollution, and other tangible threats. ${ }^{80}$ Accordingly, Puerto Rico had an interest in protecting residents from the harmful effects of discrimination. ${ }^{81}$ Puerto Rico's interest was particularly strong given the pervasiveness of ethnic discrimination. ${ }^{82}$ The Court further recognized Puerto Rico's parens patriae standing to assert its residents' interests in the federal employment scheme, given the Commonwealth's participation in that scheme and its legitimate concern for state unemployment. ${ }^{83}$

Massachusetts $\mathcal{V}$. Environmental Protection Agency ${ }^{84}$ is a recent example of quasi-sovereign interest standing in an action against, not another state, but the federal government. In Massachusetts v. Environmental Protection Agency, the Supreme Court considered a challenge to the Environmental Protection Agency's (EPA) refusal to regulate greenhouse gases that were contributing to global warming. ${ }^{85}$ The Court recognized that absent the plaintiff-states, it would have been difficult for any private individuals or organizations to "allege "particularized injuries' to themselves," as opposed to "humanity at large," as a result of global warming. ${ }^{86}$ The generalized harm of rising sea levels and loss of coastal property was a "far cry" from the type of harm typically cognizable under Article III. ${ }^{87}$ But state intervention, particularly that of Massachusetts, which owned much of the affected territory, preserved standing and allowed the Court to exercise jurisdiction. ${ }^{88}$ "That these climate-change risks are 'widely shared' does not minimize Massachusetts' interest in the outcome of this litigation." 89 Further recognizing Massachusetts's "stake in protecting its quasi-sovereign interests," the Court gave "special solicitude" to the Commonwealth's assertion of standing. ${ }^{90}$ Applying established injury-in-fact and redressability requirements for standing, the Court concluded that the EPA's refusal to regulate greenhouse gas emissions created actual and imminent risk of harm to Massachusetts, and that judicial intervention likely would prompt EPA to reduce that risk. ${ }^{91}$

State standing to challenge the ACA's individual health insurance mandate, arguably, could be asserted on the basis of sovereign or quasi-sovereign interests. States clearly have a sovereign interest in expansion of Medicaid eligibility. ${ }^{92}$ From

${ }^{80} \mathrm{Id}$. at 609 ; Schapiro, supra note 1 , at 992 (summarizing the case).

${ }^{81}$ Snapp, 458 U.S. at 609.

${ }^{82}$ Id.

${ }^{83}$ Id. at 609-10; see also Hawaii v. Standard Oil Co., 405 U.S. 251 (1972) (allowing state standing in antitrust action on proprietary and parens patriae grounds).

84 549 U.S. 497 (2007).

${ }^{85} \mathrm{Id}$. at 504 .

${ }^{86} \mathrm{Id}$. at 514-15 (quoting Massachusetts v. Envtl. Prot. Agency, 415 F.3d 50, 60 (2005) (Sentelle, J., dissenting)).

${ }^{87}$ Id. at 515 (quoting Massachusetts, 415 F.3d at 66 (Tatel, J., dissenting))

${ }^{88} \mathrm{Id}$. at 522 ("Because the Commonwealth 'owns a substantial portion of the state's coastal property,'... it has alleged a particularized injury in its capacity as a landowner." (internal citation omitted))

${ }^{89}$ Id. (citing and quoting FEC v. Akins, 524 U.S. 11, 24 (1998)).

${ }^{90} \mathrm{Id}$. at 520 .

${ }^{91} I d$. at 521 .

${ }^{92}$ See Woolhandler \& Collins, supra note 1, at 508-09 (urging that "courts should allow states standing to challenge federal legislation that regulates state administrative machinery directly" and citing cases, including New York $v$. United States). Unlike the Commonwealth of Massachusetts, in Mellon, states challenging ACA's Medicaid provisions long ago agreed to participate in that cooperative program. 
that clear basis for standing, states might bootstrap standing to challenge the individual mandate by asserting that the mandate is likely to have a "woodwork effect" of more individuals applying and qualifying for Medicaid, thereby increasing states' financial burden. ${ }^{93}$ Alternatively, states that have enacted so-called Health Care Freedom Acts (HCFAs) ${ }^{94}$ purporting to shield state residents from the federal mandate to obtain health insurance, might assert sovereign interest in enforcing their own state laws. "95 The Court's "special solicitude" for state standing in Massachusetts v. Environmental Protection Agency, and recognition of states' quasisovereign interests in protecting individual citizens' health and well-being in Snapp, might extend to the ACA context. Under either theory, however, states, would still need to assert actual or imminent risk of harm to their own interests as states, rather than the interests of individual state residents, resulting from the minimum essential coverage requirement.

\section{LOWER COURT ACA STANDING DECISIONS}

In granting certiorari in Florida v. Department of Health \& Human Services, the Supreme Court agreed to hear some procedural issues but not the standing question. ${ }^{96}$ As long as an individual plaintiff or the association remains involved in the lawsuit, the individual mandate issue is properly raised ${ }^{97}$ Likewise, as long as states remain plaintiffs, the Medicaid issue is properly raised. ${ }^{98}$ Lower courts hearing ACA challenges, brought by various individual and state litigants, reached different outcomes on the standing issues before them.

As the following description of cases shows, at least one circuit court firmly held that a state cannot litigate individual residents' interests in opposing the individual mandate. The only other circuit court to hear the question whether a state had standing to challenge the individual mandate dodged it. In a few cases, public officials asserted standing to raise states' interests, but courts uniformly rejected those claims unless the officials also evidenced concrete, particularized injury to

\footnotetext{
${ }^{93}$ See Florida ex rel. Attorney Gen. v. Dep't of Health \& Human Servs., 648 F.3d 1235, 1243 (11th Cir. 2011), cert. granted sub nom. Nat'1 Fed'n of Indep. Bus. v. Sebelius, 132 S. Ct. 603 (2011) (mem.), and cert. granted, 132 S. Ct. 604 (2011) (No. 11-398) (mem.) (argued Mar. 26-27, 2012), and cert. granted in part, 132 S. Ct. 604 (2011) (No. 11-400) (mem.) (argued Mar. 28, 2012); infra Part III (discussing state standing analysis in the case).

${ }^{94}$ See, e.g., Va. Code Ann. $\$ 38.2-34301: 1$ (2010) ("No resident of this Commonwealth . . . shall be required to obtain or maintain a policy of individual health insurance coverage."). See generally ThE TENTH AMENDMENT CTR., Health CARE Freedom ACT, http://tenthamendmentcenter.com/nullification/health-care/

${ }^{95}$ See Virginia ex rel. Cuccinelli v. Sebelius, 702 F. Supp. 2d 598 (E.D. Va. 2010), rev'd, 656 F.3d 253 (4th Cir. 2011), petition for cert. filed, 80 U.S.L.W. 3221 (U.S. Sept. 30, 2011 ) (No. 11 420); Schapiro, supra note 1, at 998-1002 (discussing district court opinion and suggesting that state involvement facilitated justiciability of the claim).

${ }^{96}$ The Court agreed to hear arguments on whether the individuals' challenge to the individual mandate is barred by the Anti-Injunction Act, Dep't of Health \& Human Servs, 132 S. Ct. 604 (No. 1 1-400), and whether the individual mandate, if unconstitutional, is severable from the rest of $\mathrm{ACA}$, Nat'l Fed'n of Indep. Bus., 123 S. Ct. 604.

${ }^{97}$ See supra note 10 (describing substitution of individual plaintiffs in the Florida lawsuit before the Supreme Court).

${ }^{98}$ Cf. Douglas v. Indep. Living Ctr. of S. Cal., 132 S. Ct. 1204 (2012) (regarding whether individual Medicaid beneficiaries and providers can bring Supremacy Clause challenge to enjoin states' compliance with federal medical requirements); see also Douglas v. Indep. Living Ctr. of Southern California, OYEZ (Mar. 28, 2012), http://www.oyez.org/cases/2010$2019 / 2011 / 201109958$.
} 
themselves. Regarding individual citizens' standing, several courts questioned whether plaintiffs alleged injury-in-fact as a result of the individual mandate. But as long as plaintiffs made proper recitations of present-day particularized injury, courts allowed them to assert structural federalism challenges. The courts that did not dismiss cases on standing were divided on the merits of the ACA's constitutionality.

\section{A. Cases ReCognizing Standing ${ }^{99}$}

Five lower court decisions recognized individual plaintiffs' standing to challenge the individual mandate as long as the plaintiffs alleged facts demonstrating present-day injury-in-fact resulting from the future effective date of the mandate. Courts generally rejected as too speculative defendants' suggestions that some or all plaintiffs might have changed circumstances and, thus, would not necessarily be subject to the individual mandate and its penalty for non-compliance. One large employer plaintiff had standing to challenge the employer penalty for failing to offer health insurance plans to employees, based on allegations that it, like the individual plaintiffs, was forced to change its current business and financial practices to prepare for the 2014 effective date of the ACA's employer responsibility provisions.

One circuit court also recognized, at least in theory, state standing to challenge the individual mandate, although that conclusion was not necessary because individual plaintiffs involved in the same suit also had standing. According to another court, public officials did not have standing based on their official status and political objections to ACA or federal health reform policy.

\section{Florida ex rel. Bondi v. Department of Health \& Human Services ${ }^{100}$}

Florida v. Department of Health \& Human Services, the case now before the Supreme Court, ${ }^{101}$ originated in the Northern District of Florida before Judge Roger Vinson. In a sweeping opinion that ultimately struck down the individual mandate as unconstitutional and not severable from the rest of $\mathrm{ACA},{ }^{102}$ Judge Vinson first held that the two individuals challenging the individual mandate had standing. ${ }^{103}$ Judge Vinson's ruling was based on the individuals' declarations that the mandate, although not in effect until 2014 , required them presently to investigate the impact that compliance with the individual mandate would have on their personal and business finances. ${ }^{104}$ Mary Brown, a small business owner and member of the association plaintiff NFIB, asserted that requiring her to purchase health insurance, which she neither wanted nor needed, threatened her ability to operate her business. ${ }^{105}$ Kaj Ahlburg, an unemployed retiree who was too young to qualify for

${ }^{99}$ See infra Appendix A.

${ }^{100} 780$ F. Supp. 2d 1256 (N.D. Fla.), order clarified, 780 F. Supp. 2d 1307 (N.D. Fla.), aff'd in part, rev'd in part, 648 F.3d 1235 (11 th Cir. 2011), cert. granted sub nom. Nat'l Fed'n of Indep. Bus. v. Sebelius, 132 S. Ct. 603 (2011) (mem.), and cert. granted, 132 S. Ct. 604 (2011) (No. 11-398) (mem.) (argued Mar. 26-27, 2012), and cert. granted in part, 132 S. Ct. 604 (2011) (No. 11-400) (mem.) (argued Mar. 28, 2012).

${ }_{101}$ Nat'l Fed. of Indep. Bus., 132 S. Ct. 603 (No. 11-393) (mem.); Florida, 132 S. Ct. 604 (No. 11-398) (mem.); Dep't of Health \& Human Servs., 132 S. Ct. 604 (No. 11-400) (mem.).

${ }^{102}$ See Florida ex rel. Att'y Gen., 648 F.3d at 1305-06 (11th Cir. 2011).

${ }^{103} \mathrm{Id}$. at 1272 .

${ }^{104}$ Id. at 1270-71; see also Florida, 716 F. Supp. 2d 1120, 1144-48 (N.D. Fla. 2010) (discussing defendants' motion to dismiss for lack of subject matter jurisdiction).

${ }^{105}$ Florida ex rel. Bondi, 780 F. Supp. 2d at 1270-71. 
Medicare, similarly asserted that forcing him to purchase health insurance was not a sensible use of his financial resources and would require him to divert funds from other personal and family priorities. ${ }^{106}$ The court noted that most other district courts deciding the individual standing issue held similarly, based on the present-day economic pressures that individuals face in planning for the 2014 effective date of the individual mandate. ${ }^{107}$ Judge Vinson further held that "[b]ecause the individual plaintiffs have demonstrated standing, including NFIB member Mary Brown, that means ... that NFIB has associational standing as well." 108

On the question of states' standing, Judge Vinson noted that at least two of the plaintiff-states, Idaho and Utah, had passed legislation protecting their citizens from any requirement to purchase health insurance. Judge Vinson held that those two states had adequate standing based on the existence of a validly enacted state law, which triggered the duty of the states' attorneys general "to defend the law and the associated sovereign power to enact it." $" 109$ As long as some of the plaintiff-states had standing, there was no need to consider the remaining states' assertions of standing to challenge the individual mandate. ${ }^{110}$

The Eleventh Circuit largely affirmed the district court's standing analysis, first noting that the federal government did not contest the standing of the individual plaintiffs or NFIB, nor the states' interests in challenging the Medicaid expansion. ${ }^{111}$ The only remaining question was whether the states had standing to challenge the individual mandate. ${ }^{112}$ The states firmly rejected the suggestion that their standing was based on parens partriae, as representatives of their citizens. ${ }^{113}$ Instead, they asserted standing to challenge the individual mandate on three grounds: first, the individual mandate would necessarily increase Medicaid enrollment, thereby burdening states; second, if any unconstitutional provisions of the ACA were not severable, states' clear standing to challenge Medicaid expansion would also give them standing to challenge the individual mandate; and, third, the federal mandate infringed on state sovereignty to enforce state laws, such as Utah's, Idaho's, and other states' HCFAs, which expressly shield state residents from any requirement to maintain insurance. ${ }^{114}$ The first assertion turned out to be the key to state standing to challenge the individual mandate. By the time the Eleventh Circuit ruled, the Fourth Circuit had rejected the third ground in Virginia's go-it-alone ACA lawsuit. ${ }^{115}$ The second ground ultimately was unavailing because the Eleventh Circuit, although striking down the individual mandate, held it severable from the rest of ACA. That

${ }^{106} I d$. at 1270.

${ }^{107} \mathrm{Id}$. at $1271-72$

${ }^{108}$ Id. at 1272

${ }^{109}$ Id. (quoting Virginia ex rel. Cuccinelli v. Sebelius, 702 F. Supp. 2d 598, 605-06 (E.D. Va. 2010), rev'd, 656 F.3d 253 (4th Cir. 2011), petition for cert. filed, 80 U.S.L.W. 3221 (U.S. Sept. 30, 2011) (No. 11-420). See infra Part III.B.1 for a discussion of the Virginia standing decision, ultimately overruling Judge Hudson's opinion.

${ }^{110}$ Florida ex rel. Bondi, 780 F. Supp. 2 d at 1273

"See Florida ex rel. Att'y Gen. v. U.S. Dep't of Health \& Human Servs., 648 F.3d 1235 (11th Cir. 2011), cert. granted sub nom. Nat'l Fed'n of Indep. Bus. v. Sebelius, 132 S. Ct. 603 (2011) (mem.), and cert. granted, 132 S. Ct. 604 (2011) (No. 11-398) (mem.) (argued Mar. 26-27, 2012), and cert. granted in part, 132 S. Ct. 604 (2011) (No. 11-400) (mem.) (argued Mar. 28, 2012).

${ }_{112} I$ d.

${ }^{113} \mathrm{Id}$.

${ }^{114} \mathrm{Id}$.

115 See Virginia ex rel. Cuccinelli v. Sebelius, 656 F.3d 253, 272 (4th Cir. 2011), petition for cert. filed 80 U.S.L.W. 3221 (U.S. Sept. 30, 2011 ) (No. 11-420), 
left just the Medicaid bootstrap grounds for standing. Regardless, the presence and clear standing of the individual and association plaintiffs to challenge the individual mandate rendered the state standing question "purely academic and one that [the court] need not confront." ${ }^{\text {"16 }}$ As long as at least one plaintiff has standing on each claim, the court need not address whether the remaining plaintiffs have standing on that issue.

\section{Thomas More Law Center v. Obama ${ }^{117}$}

Plaintiffs in Thomas More Law Center v. Obama, a Sixth Circuit opinion that upheld the individual mandate as constitutional under the commerce power, ${ }^{118}$ involved a public interest law firm and four individuals. The law firm did not claim any injury to itself as an employer, asserting only claims on behalf of its members, two of the individuals. ${ }^{199}$ The individuals were U.S. citizens, Michigan residents, and federal taxpayers who claimed that the individual mandate would compel them to purchase health insurance. ${ }^{120}$ The individuals declared that the impending requirement to purchase health insurance changed their present spending and saving habits. ${ }^{121}$ They further alleged imminent future injury by operation of the January 1 , 2014 , effective date of the individual mandate. ${ }^{122}$ The court deemed suggestions that the individuals could die, leave the country, or become exempt from the individual mandate requirement too speculative to defeat standing. ${ }^{123}$ Moreover, the fact that one of the plaintiffs purchased insurance after filing the lawsuit did not alter the court's decision because ACA requires individuals not only to obtain, but also to maintain, minimum essential coverage. ${ }^{124}$

The court concluded: "In view of the probability, indeed virtual certainty, that the minimum coverage provision will apply to the plaintiffs on January 1, 2014, no function of standing law is advanced by requiring plaintiffs to wait until six months or one year before the effective date to file this lawsuit." 25 Moreover, by permitting the lawsuit to be filed presently, "all three layers of the federal judiciary will be able to reach considered merits decisions, as opposed to rushed interim (e.g., stay) decisions." ${ }^{126}$ Having found standing, ${ }^{127}$ the court reached the merits of the plaintiffs' challenge and held that the minimum coverage requirement was a valid exercise of the federal commerce power. ${ }^{128}$

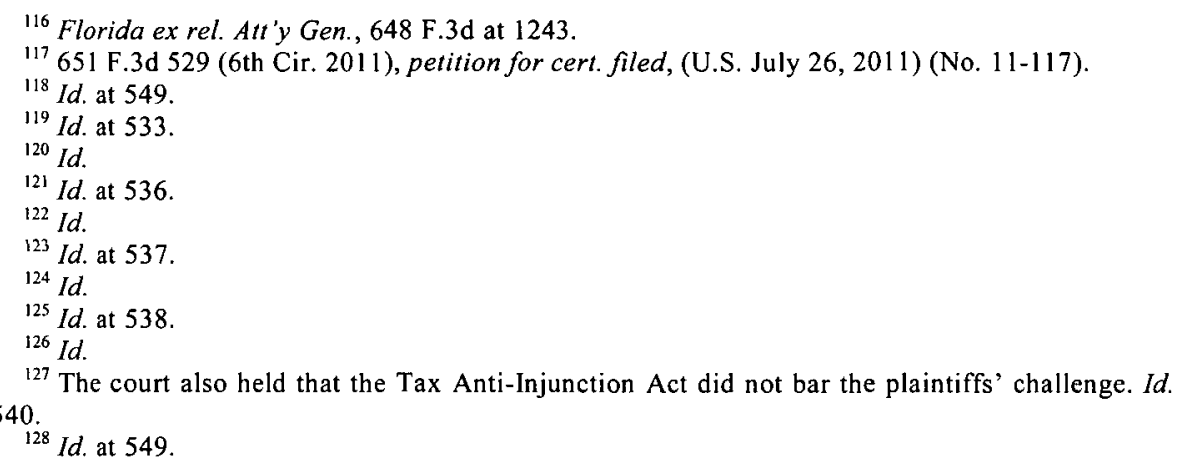




\section{Liberty University v. Geithner ${ }^{129}$}

A variety of plaintiffs, including public officials, individuals, a physician, and a large employer, challenged the individual mandate in Liberty University $v$. Geithner. ${ }^{130}$ The district court dismissed three of the plaintiffs for lack of standing but allowed claims by three others to go forward. ${ }^{131}$ The first two dismissed plaintiffs' asserted standing in their status as lawmakers and based on their policy objections to the federal law. Kathy Byron, a member of the Virginia House of Delegates, voted for Virginia's HCFA, and Jeff Helgeson, a Lynchburg, Virginia, city council member, believed that ACA would have a negative impact on the city. ${ }^{132}$ Neither alleged personal injury by operation of the individual mandate or current lack of health insurance. ${ }^{133}$ The court held their asserted grounds for standing unavailing. ${ }^{134}$ The court also dismissed Dr. David Stein, who asserted standing based on speculation that the ACA's regulations would adversely impact his Medicare and Medicaid reimbursement rates and his liberty interests in practicing his profession and providing care to his patients. ${ }^{135}$ The court found those pleadings too vague and conclusory to support standing. ${ }^{136}$

The case also involved two other individuals and a non-profit corporation, Liberty University. The individuals, Michele Waddell and Joanne Merrill, alleged that the individual mandate, at the present time, required them to make changes to their personal finances and lifestyles to comply with the new law. ${ }^{137}$ Liberty University, which employed 3900 full-time employees, challenged the ACA's requirement that employers of fifty or more full-time employees offer minimum essential health insurance to their employees or face civil penalties. ${ }^{138}$ Liberty University alleged that it would "incur 'significant and costly changes' in its daily business operations well before 2014 " to provide the required coverage. ${ }^{139}$ The court held the allegations of these three plaintiffs sufficient to support standing. ${ }^{140}$

On appeal, the Fourth Circuit addressed only the latter three plaintiffs' claims and did not review the standing question. ${ }^{141}$ Rather than dismissing the individuals and Liberty University for lack of standing, the court held that all claims were barred as pre-enforcement actions seeking to enjoin the ACA's individual mandate and employer penalty provisions. ${ }^{142}$ According to the court, the challenged provisions constituted "taxes" for purposes of the Federal Tax Anti-Injunction Act (TAIA) and, therefore, were jurisdictionally barred. ${ }^{143}$ This procedural question, but not the

129753 F. Supp. 2d 611 (W.D. Va. 2010), vacated, No. 10-2347, 2011 WL 3962915 (4th Cir. Sept. 8, 2011), petition for cert filed, 80 U.S.L.W. 3240 (U.S. Oct. 7, 2011 ) (No. 11-438).

130 This lawsuit was separate from the Commonwealth of Virginia's lawsuit challenging the individual mandate. See infra Part IIl.B.1 (discussing Virginia's solo lawsuit).

${ }_{131}$ See Liberty Univ., 753 F. Supp. 2d at $621-22,626$.

${ }^{132} I d$. at 621 n. 6.

${ }^{133} \mathrm{Id}$.

${ }^{134}$ Id. at 621 .

${ }^{135}$ Id. at 622 n.7.

${ }^{136} \mathrm{Id}$.

${ }^{137} \mathrm{Id}$. at 623.

${ }^{138}$ Id. at 622.

${ }^{139} I d$. at $622-23$.

${ }^{140} \mathrm{Id}$. at 626.

${ }^{141}$ See Liberty Univ. v. Geithner, No. 10-2347, 2011 WL 3962915 (4th Cir. 2011), petition for cert filed, 80 U.S.L.W. 3240 (U.S. Oct. 7, 2011 ) (No. 11-438).

${ }_{142}$ Id. at $* 14$.

${ }^{143} I d$. at *4; see 26 U.S.C. $\S 7421$ (2006) (providing that "no suit for the purpose of restraining the assessment or collection of any tax shall be maintained in any court by any person"). 
underlying standing issue, is before the Supreme Court in a separate grant of certiorari. $^{144}$

\section{Seven-Sky v. Holder ${ }^{145}$}

Seven-Sky v. Holder involved four U.S. citizens and federal taxpayers seeking declaratory and injunctive relief to prevent the individual mandate's enforcement. ${ }^{146}$ As in other cases, the individuals asserted imminent future injury based on the penalty that they would be required to pay, beginning in 2014 , for failing to obtain minimum essential coverage. ${ }^{147}$ They also alleged present actual injury by having to rearrange their finances to prepare for the mandate's 2014 effective date. ${ }^{148}$ One of the individuals, Mary Mead, would have been eligible for Medicare by the time the individual mandate took effect, but nonetheless asserted that she would refuse to enroll when she became eligible. ${ }^{149}$ Even setting Mead aside, the remaining plaintiffs, absent some change in life circumstances, would be subject to the penalty in 2014. ${ }^{150}$ Like the Sixth Circuit in Thomas More, the D.C. District Court did not insist on "absolute certainty" that the individuals would be penalized for failing to have insurance in $2014 .^{151}$ The substantial probability that they would be adversely affected sufficed. ${ }^{152}$ Moreover, their present-day conduct to prepare for the future mandate sufficed for injury-in-fact. ${ }^{153}$ The plaintiffs alleged that the pending individual mandate required them to forgo spending discretionary income, donating to charity, paying down debt, and saving for their children's college education. ${ }^{154}$

On the merits, the district court granted the federal government's motion to dismiss, upholding the mandate under the Commerce Clause and Necessary and Proper Clause, but rejecting the plaintiff's Religious Freedom and Restoration Act (RFRA) claim. ${ }^{155}$ The D.C. Circuit Court affirmed dismissal of the RFRA claim. ${ }^{156}$ The appellate court considered at some length, and Judge Kavanaugh wrote an even longer dissent on, ${ }^{157}$ the application of the Federal TAIA to bar a pre-enforcement challenge to the minimum essential coverage requirement. ${ }^{158}$ The court ultimately

${ }^{144}$ See Dep't of Health \& Human Servs. v. Florida, 132 S. Ct. 604 (2011) (No. 11-400) (mem.) (granting review of question "[w]hether the suit brought by respondents to challenge the minimum coverage provision of the Patient Protection and Affordable Care Act is barred by the Anti-Injunction Act, 26 U.S.C. $\$ 7421$ (a)").

${ }^{145} 661$ F.3d 1 (D.C. Cir. 2011).

${ }^{146} I d$. at 5 .

${ }^{147}$ See, e.g., Mead v. Holder, 766 F. Supp. 2d 16, 23 (D.D.C. 2011), en banc denied sub nom. Seven-Sky v. Holder, 2011 WL 1113489 (D.C. Cir. Mar 17, 2011), aff'd, 661 F.3d 1 (D.C. Cir. 2011), petition for cert. filed, 80 U.S.L.W. 3359 (U.S. Nov. 30, 2011) (No. 11-679).

${ }^{148} I d$.

${ }^{149} I d$.

${ }^{150} I d$. at 24 (agreeing with Judge Vinson that speculative changed circumstances before or in 2014 did not defeat standing).

${ }^{151} I d$.

${ }^{152}$ Id. at 24-25 (citing Sierra Club v. Envtl. Prot. Agency, 292 F.3d 895, 899 (D.C. Cir. 2002)).

${ }^{153} \mathrm{Id}$. at 26.

${ }^{154} I d$.

${ }^{155} I d$. at $33-35$.

${ }^{156}$ Seven-Sky v. Holder, 661 F.3d 1, 5 n.4 (D.C. Cir. 2011), petition for cert. filed, 80 U.S.L.W. 3359 (U.S. Nov. 30, 2011) (No. 11-679). merits).

${ }^{157}$ See id. at 21-54 (Kavanaugh, J., dissenting) (dissenting as to jurisdiction and not deciding the

${ }^{158} I d$. at 5-14. 
reached the merits, however, and upheld the mandate as falling within Congress's commerce power. $^{159}$

\section{Goudy-Bachman v. Department of Health \& Human Services ${ }^{160}$}

Plaintiffs Barbara Goudy-Bachman and Gregory Bachman, a married couple with two children, challenged the individual mandate in the Middle District of Pennsylvania. They alleged injury-in-fact on the basis that they were self-employed, did not carry health insurance, did not qualify for Medicaid, and would not qualify for Medicare by January 1, 2014. They also were not members of any groups exempt from compliance with the individual mandate. ${ }^{161}$ The plaintiffs dropped their own health insurance in 2001 when the premiums exceeded their mortgage payments and since then have paid for their healthcare costs out-of-pocket. ${ }^{162}$ They further averred that they did not purchase a new car, which they otherwise could afford, because they would be unable to afford the payments in 2014 when the individual mandate took effect. ${ }^{163}$ Comparing the Bachmans' averments to plaintiffs' averments in other ACA litigation, the district court held that the Bachmans alleged sufficient economic injury to support standing. ${ }^{164}$ The economic impact was immediate in having to forgo the vehicle purchase and undertake financial planning and budget decisions in anticipation of 2014. ${ }^{165}$ Accordingly, the Bachmans alleged the constitutional minimum for standing. ${ }^{166}$ On the merits, the district court concluded that the individual mandate exceeded congressional power to regulate interstate commerce. $^{167}$

\section{B. CASES DENYING STANDING ${ }^{168}$}

Almost twice as many lower court ACA decisions denied standing as recognized standing. The cases denying standing were brought by a state, state officials, employers, physicians, individuals, patients, and associations. The one case involving a state challenged only the individual mandate and was dismissed on the grounds that the state alleged injury to its citizens' rights, not its own sovereign interests. Most of the individual plaintiffs' claims were dismissed for failing to allege sufficient injury-in-fact. One group of plaintiffs was allowed to amend their pleadings, thereafter reciting the necessary allegations. State officials fared no better than individuals, even when asserting state interests, because they again failed to allege personal, concrete injury. Employers, including one state, failed to allege how ACA was applicable to them.

${ }^{159}$ Id. at 20. The plaintiffs have also sought Supreme Court review of this decision. Petition for Writ of Certiorari, Seven-Sky, 661 F.3d 1 (No. 11-679), available at http://acalitigation.wikispaces.com/file/view/Cert+petition+\%2811.30.2011\%29.pdf.

${ }^{160}$ No. 1:10-CV-763, 2011 WL 4072875 (M.D. Pa. 2011); see also Goudy-Bachman v. Dep't of Health \& Human Servs., 764 F. Supp. 2d 684 (M.D. Pa. 2011).

${ }^{161}$ See Goudy-Bachman, 2011 WL 4072875, at *1.

162 Id. at $* 2$

${ }^{163} \mathrm{Id}$. at $* 2$ n.3 (citing trial court record); 764 F. Supp. 2d. at 690-91 (summarizing plaintiffs' assertions).

${ }^{164}$ Goudy-Bachman, 2011 WL 4072875, at *2; Goudy-Bachman, 764 F. Supp. 2d at 691-92.

${ }^{165}$ Goudy-Bachman, 764 F. Supp. 2d at 691-92.

${ }^{166} \mathrm{Id}$. at 692 .

${ }^{167}$ Goudy-Bachman, 2011 WL 4072875, at *1.

${ }^{168}$ See infra Appendix B. 


\section{Virginia v. Sebelius ${ }^{169}$}

In what now seems like a strategic miscalculation, Virginia, and later Oklahoma, ${ }^{170}$ filed lawsuits separate from the other twenty-six state plaintiffs, challenging only the individual mandate. These two states may have opted to file separately with the idea that they would have stronger sovereign interest standing than other states' general Tenth Amendment challenges. Virginia alleged that the minimum essential coverage requirement in ACA directly conflicted with the Virginia Health Care Freedom Act (VHCFA). ${ }^{171}$ Virginia alleged unique injury to its sovereign interest in enforcing a validly enacted state law, which ACA contravened. ${ }^{172}$ That suggestion was echoed by the American Legislative Exchange Council's playbook, State Legislatures Guide to Repealing ObamaCare, urging states to enact HCFAs precisely for the purpose of "provid[ing] standing to a state participating in current litigation against the federal individual mandate." 173 At least initially, the strategy seemed effective.

Virginia challenged only the individual mandate, not Medicaid expansion or other ACA provisions, asserting that the federal individual health insurance mandate exceeded Congress's enumerated powers and conflicted with existing state law. ${ }^{174}$ Virginia expressly disclaimed any parens partiae or quasi-sovereign interest in asserting the rights of its residents ${ }^{175}$ and instead asserted its own sovereign interest in vindicating VHCFA. ${ }^{176}$ Judge Henry Hudson of the Eastern District of Virginia was persuaded, noting that "the Commonwealth is exercising a core sovereign power because the effect of the federal enactment is to require Virginia to yield under the Supremacy Clause." 177 The court further noted, "The power to create and enforce a legal code' is one of the quintessential functions of a state." ${ }^{178}$ The state's participation in the lawsuit did not impede, but in fact facilitated, the justiciability of the claim, which the TAIA or ripeness doctrine might have barred if brought by individuals. ${ }^{179}$ Although the minimum essential coverage provision does not take effect until 2014, individuals, insurers, and employers will feel its effects in the near future. Similarly, the Commonwealth "must revamp its health care programs to ensure compliance with the enactment's provisions." ${ }^{180}$ Judge Hudson concluded that Virginia stated a plausible claim that the individual mandate exceeded

\footnotetext{
${ }^{169} 656$ F.3d 253 (4th Cir. 2011), petition for cert. filed 80 U.S.L.W. 3221 (U.S. Sept. 30, 2011) (No. 11-420).

${ }^{170}$ See Complaint for Declaratory and Injunctive Relief, Oklahoma v. Sebelius, No. 6:11-CV. 00030 (E.D. Okla. Jan. 21, 2011).

${ }^{171}$ Virginia ex rel. Cuccinelli, 656 F.3d at 268. The Virginia HCFA provides: "No resident of this Commonwealth ... shall be required to obtain or maintain a policy of individual health insurance coverage ..."VA. CODE ANN. $\$ 38.2-34301: 1$ (2010).

${ }^{172}$ Virginia ex rel. Cuccinelli, 656 F.3d at 268.

${ }^{173}$ AM. LEgISLATIVE EXCH. COUNCIL, STATE LEgISLATURES GuIDE TO REPEALING OBAMACARE 12 (2011), available at http://www.alec.org/wp-content/uploads/State_Leg_Guide_to_Repealing ObamaCare.pdf.

${ }^{174}$ Virginia ex rel. Cuccinelli, 656 F.3d at 266 (noting that "Virginia challenges one provision of the Patient Protection and Affordable Care Act").

${ }^{175}$ Virginia ex rel. Cuccinelli v. Sebelius, 702 F. Supp. 2d 598, 603 (E.D. Va. 2010), rev'd 656 F.3d 253 (4th Cir. 2011), petition for cert. filed 80 U.S.L.W. 3221 (U.S. Sept. 30, 2011) (No. 11-420).

${ }^{176} \mathrm{Id}$.

${ }^{177} I d$.

${ }^{178}$ Id. (citing Alfred L. Snapp \& Son, Inc. v. Puerto Rico, 458 U.S. 592 (1982)).

${ }^{179}$ See id. at 604-05 (discussing TAIA); id. at 607-08 (discussing ripeness); Schapiro, supra note 1, at 999-1001 (noting that state's involvement overcame ripeness and TAIA obstacles).

${ }^{180}$ Virginia ex rel. Cuccinelli, 702 F. Supp. $2 \mathrm{~d}$ at 608.
} 
Congress's power under the Commerce Clause, at least sufficient to survive dismissal on the pleadings. ${ }^{181}$

The Fourth Circuit, however, reversed the district court's standing decision. The essence of Virginia's claim, according to the appellate court, was "to litigate as parens patriae by asserting the rights of its citizens." ${ }^{182}$ Under the well-established Mellon doctrine, ${ }^{183}$ the court declined to recognize any cognizable state interest in protecting a state's residents from operation of a federal statute. ${ }^{184}$ The Fourth Circuit dismissed the VHCFA as merely "a smokescreen for Virginia's attempted vindication of its citizens' interests." 185 Moreover, a state could not "acquire some special stake in the relationship between its citizens and the federal government merely by memorializing its litigation posture in a statute." ${ }^{186}$ Accordingly, the court denied Virginia standing to challenge the individual mandate. The federal government has moved to dismiss the Oklahoma case on similar grounds. ${ }^{187}$

The Eleventh Circuit, in Florida v. Department of Health \& Human Services, ${ }^{188}$ was able to reach a different conclusion on standing because plaintiffs included both state and private plaintiffs who brought challenges to both the individual mandate and Medicaid expansion. ${ }^{189}$ Virginia's go-it-alone strategy, as it turned out, was flawed in at least three respects: first, by failing to include an individual litigant to challenge the individual mandate, ${ }^{190}$ or a Medicaid challenge in which the state of Virginia had a clear interest; ${ }^{191}$ second, for believing that enacting a state statute contrary to ACA could create an injury-in-fact where such otherwise did not exist; and third, for failing to assert concrete, particularized injury to its own interests in preparing for the individual mandate's future effective date.

2. Baldwin v. Sebelius ${ }^{192}$

A California case highlights the type of allegations that individuals, employers, and associations must make to challenge the individual mandate. The Ninth Circuit

${ }^{181} I d$. at 612 .

182 Virginia ex rel. Cuccinelli, 656 F.3d at 268.

${ }^{183}$ Massachusetts v. Mellon, 262 U.S. 447, 485-86 (1923); see supra Part II.B (discussing Mellon doctrine)

${ }^{184}$ Virginia ex rel. Cuccinelli, 656 F.3d at 269; see Timothy Stoltzfus Jost \& Mark A. Hall, Not So Fast-Jurisdictional Barriers to the ACA Litigation, 365 NEW ENG. J. MED. e34(1), e34(2) (2011) (noting Fourth Circuit's holding "invoking well-settled law that states may not sue to protect their citizens from federal law, since state citizens are also federal citizens"), available at http://www.nejm.org/doi/pdf/10.1056/NEJMpl111295.

${ }^{185}$ Virginia ex rel. Cuccinelli, 656 F.3d at 269.

${ }^{186} \mathrm{Id}$. at 271 .

${ }^{187}$ Memorandum in Support of Defendants' Motion to Dismiss the Complaint, Oklahoma v. Sebelius, No. 6:11-CV-00030-RAW (E.D. Okla. Mar. 28, 2011), available at http://acalitigation.wikispaces.com/file/view/U.S.+motion+to+dismiss+\%2803.28.11\%29.pdf.

${ }^{188}$ See supra Part III.A.l (describing the Florida decision).

${ }^{189}$ Florida ex rel. Att'y Gen. v. Dep't of Health \& Human Servs., 648 F.3d 1235, 1243 (11 th Cir. 2011), cert. granted sub nom. Nat'l Fed'n of Indep. Bus. v. Sebelius, 132 S. Ct. 603 (2011) (mem.), and cert. granted, 132 S. Ct. 604 (2011) (No. 11-398) (mem.) (argued Mar. 26-27, 2012), and cert. granted in part, 132 S. Ct. 604 (2011) (No. 11-400) (mem.) (argued Mar. 28, 2012).

${ }^{190}$ See, e.g., Thomas More Law Ctr. v. Obama, 651 F.3d 529, 536 (6th Cir. 2011), petition for cert. filed, (U.S. July 26, 2011) (No. 11-117) (noting that individual plaintiffs demonstrated actual injury by showing that impending requirement to buy health insurance changed their spending and saving habits).

${ }^{191}$ See Florida ex rel. Att'y Gen., 648 F.3d at 1244 (concluding that "the state plaintiffs undeniably have standing to challenge the Medicaid provisions").

${ }^{192} 654$ F.3d 877 (9th Cir. 2011). 
ultimately denied standing to Steve Baldwin, a former member of the California legislature, and the Pacific Justice Institute ("Institute"), a legal defense organization. ${ }^{193}$ Baldwin challenged the individual mandate as exceeding Congress's authority under Article I but asserted no particularized injury. ${ }^{194}$ The court rejected plaintiff Baldwin's asserted standing to raise a generalized grievance about government, "claiming only harm to his and every citizen's interest in proper application of the Constitution and laws." 195 Baldwin failed to aver that he currently lacked qualifying health insurance, would not have it in 2014, or had to save money now to purchase it in 2014. ${ }^{196}$ According to the Ninth Circuit, Baldwin's suggestion that he had to take investigatory steps to determine whether he would be in compliance with the law did not establish a particularized injury distinct from everyone else to whom the ACA applies. ${ }^{197}$

The Institute lacked standing as either an employer or association representing individuals. ${ }^{198}$ As a putative plaintiff challenging the ACA's employer penalty, the Institute failed to allege that it had more than fifty employees, which is required for the penalty to apply. ${ }^{199}$ As an association representing individuals challenging the individual mandate, the Institute lacked standing because the individuals lacked standing. ${ }^{200}$

\section{New Jersey Physicians v. Obama ${ }^{201}$}

The Third Circuit Court of Appeals denied standing in a case brought by Dr. Mario Criscito, a licensed New Jersey physician; a patient of Dr. Criscito's ("Roe"); and New Jersey Physicians, Inc., a non-profit corporation. ${ }^{202}$ The plaintiffs challenged the ACA's individual mandate and employer responsibility provisions. ${ }^{203}$ Roe asserted merely that he was a patient who paid for his own medical care. He did not allege facts demonstrating that he would be subject to the individual mandate or that the mandate, if applicable, would change his current choice to pay for his medical care out of pocket. ${ }^{204} \mathrm{Dr}$. Criscito's allegation that he was a physician who treated patients, some of whom were self-pay, was similarly insufficient for failing to allege that he was suffering or would suffer imminent, concrete injury. ${ }^{205}$ The Third Circuit held that Dr. Criscito's further allegation that the ACA would impact his medical practice and the manner in which he sought payment and treated patients was also conjectural. ${ }^{206}$ The New Jersey Physician's associational standing failed

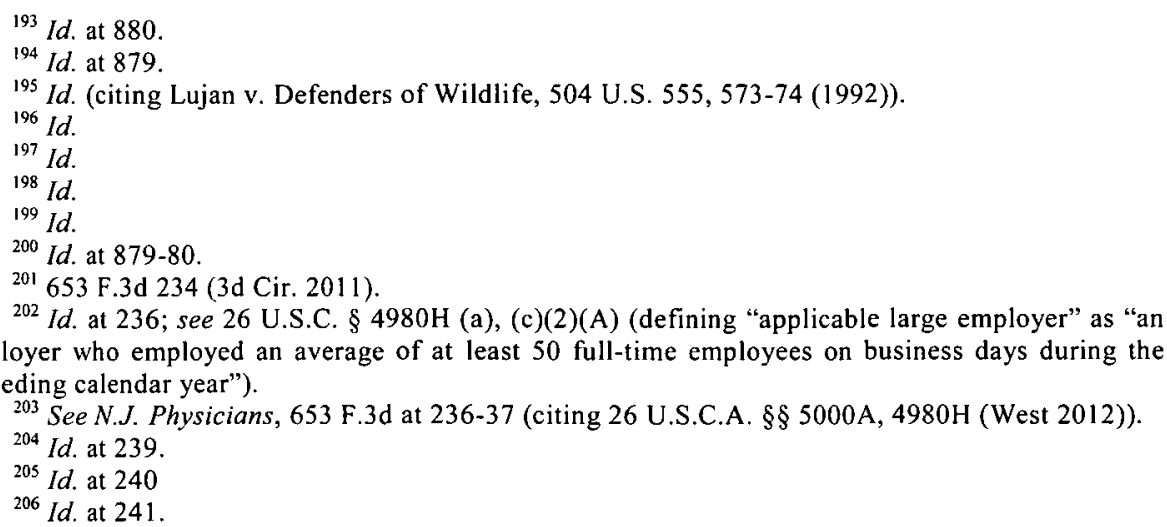


inasmuch as there was no particularized injury to the only member of the group, Dr. Criscito, identified in the complaint. ${ }^{207}$

\section{Purpura v. Sebelius ${ }^{208}$}

The Third Circuit affirmed its standing decision in New Jersey Physicians in Purpura v. Sebelius. ${ }^{209}$ Purpura involved a claim by two pro se plaintiffs, asserting only that they were New Jersey residents who believed that ACA was unconstitutional. ${ }^{210}$ The Purpura plaintiffs' allegations of standing, like Roe's allegations in New Jersey Physicians, were "factually barren." 211 The court also rejected the plaintiffs' reliance on Bond, distinguishing that case because the plaintiff's incarceration under the allegedly unlawful federal statute constituted a concrete injury, fairly redressable by invalidation of the conviction. ${ }^{212}$ By contrast, the Pupura plaintiffs alleged no concrete, particularized injury. ${ }^{213}$

\section{Bryant v. Holder ${ }^{214}$}

Another case testing standing to challenge the individual mandate involved private individuals residing in Mississippi and Mississippi's Lieutenant Governor Phil Bryant. ${ }^{215}$ The private plaintiffs asserted standing based on the threatened injury of being forced to purchase health insurance and manage their finances in preparation for complying with the mandate. ${ }^{216}$ Lieutenant Governor Bryant asserted standing as a state employee, first, because the mandate would compel the state to offer employee insurance plans complying with the ACA's requirements, and, second, because he would be unable to drop his own state employee health plan without incurring the tax penalty. ${ }^{217}$ The plaintiffs' asserted commerce power, taxing power, takings, substantive due process, and Tenth Amendment challenges to the individual mandate. ${ }^{218}$

The Southern District of Mississippi held that the ten private individual plaintiffs lacked standing because they failed to allege that they would even be subject to the individual mandate, as opposed to exempt on various grounds, and, even if subject, that they would incur the tax penalty for non-compliance. ${ }^{219} \mathrm{With}$ respect to Lieutenant Governor Bryant, the court held that he failed to allege facts to show "certainly impending" injury or that he would be subject to the tax penalty. ${ }^{220}$ Bryant's separate allegations of injury to Mississippi's sovereign interests were unavailing as asserted in his private, individual capacity. The court noted that even if

207 Id.

${ }^{208} 446$ Fed. Appx. 496 (3d Cir. 2011), cert. denied 132 S. Ct. 1037 (2012), reh'g denied, No. 11 7275, 2012 WL 538800 (U.S. Feb. 21, 2012).

$209 \mathrm{Id}$.

${ }^{210} \mathrm{Id}$. at $497-98$.

${ }^{211}$ Id. (quoting N.J. Physicians, 653 F.3d 234, 239 (3d Cir. 2011)).

${ }^{212}$ Id. (citing Bond v. United States, 131 S. Ct. 2355 (2011)).

$213 \mathrm{ld}$.

214809 F. Supp. 2d 563 (S.D. Miss. 2011); Bryant v. Holder, 2:10-CV-76-KS-MTP, 2011 WL 710693 (S.D. Miss. Feb. 3, 2011).

${ }^{215}$ Bryant, 2011 WL 710693 , at *2.

${ }^{216} \mathrm{Id}$.

$217 \mathrm{Id}$.

$218 \mathrm{Id}$.

219 Id. at $* 11$.

${ }^{220} \mathrm{Id}$. at $* 12$. 
an individual had standing to assert a Tenth Amendment claim regarding state power, he would still have to demonstrate particularized injury-in-fact. ${ }^{221}$

The ten individual plaintiffs subsequently amended their complaint to allege particularized, present-day injuries. All alleged that they were forgoing certain spending to save money to pay the ACA penalties and had made "significant and costly changes" to their lifestyles and personal finances to prepare for "the individual mandate's looming enforcement in 2014."222 In a subsequent opinion, the court deemed those amended allegations sufficient to support standing. ${ }^{223}$

The district court revisited Bryant's standing to assert Mississippi's sovereign interest after the Supreme Court's decision in United States v. Bond, ${ }^{224}$ noting the Court's holding that an individual challenging a federal statute "on the basis that it interferes with state sovereignty seeks vindication of his own constitutional interests-not just those of the state. ${ }^{, 225}$ Bond expressly recognized that federalism protects not only state sovereignty but also enhances individual freedom by diffusing power vertically between the federal government and separate states. ${ }^{226}$ Accordingly, laws that upset the constitutional structure also may give rise to individual injury. ${ }^{227}$ On the facts, however, the Mississippi court again concluded that Bryant failed to allege imminent, concrete harm inasmuch as the individual mandate was not yet in effect. Moreover, it was not certain that he would still be a state employee when it became effective. ${ }^{228}$ In sum, Bond's recognition of a private plaintiff's Tenth Amendment claim still required injury-in-fact to be justiciable.

\section{Kinder v. Geithner 229}

Several individuals, including Missouri's Lieutenant Governor Peter Kinder, challenged several provisions of ACA. Kinder received health insurance through the state and clarified that he asserted claims only in his individual capacity, not on behalf of the State of Missouri or as an advocate for other citizens. ${ }^{230}$ Other plaintiffs included elderly individuals eligible for Medicare. Another individual plaintiff was an uninsured twenty-one-year-old woman. Finally, a mother and her autistic son joined the lawsuit. ${ }^{231}$

The plaintiffs alleged multiple counts, including injuries to both individuals and the state. ${ }^{232}$ To begin, they asserted that ACA would unconstitutionally commandeer state officials by requiring the state first to establish a reinsurance program for private insurance plans and, second, to maintain health benefit plans for state employees or face a stiff penalty. ${ }^{233}$ Although Kinder previously denied any reliance

${ }^{221}$ Id. at * 12 n. 7 .

${ }^{222}$ Bryant v. Holder, 809 F. Supp. 2d 563, 567 (S.D. Miss. 2011).

${ }^{223}$ Id.

224131 S. Ct. 2355 (2011).

${ }^{225}$ Bryant, 809 F. Supp. 2 d at 568 (citing Bond, 131 S. Ct. at 2360).

${ }^{226} \mathrm{Id}$.

$227 \mathrm{Id}$.

${ }^{228} \mathrm{Id}$. at 569 .

${ }^{229} 1$ :10 CV 101 RWS, 2011 WL 1576721 (E.D. Mo. Apr. 26, 2011).

${ }^{230} \mathrm{Id}$. at *2 (noting that Kinder initially indicated that he was suing in his individual capacity and "as an advocate for the elderly" but that his amended complaint did not appear to rely on being an advocate and that basis of standing was not considered).

${ }^{231} I$ d. at $* 1$.

${ }^{232} I d$. at *4-10.

${ }^{233} I d$. at $* 4$. 
on his official status to assert standing with respect to these Tenth Amendment challenges, he alleged specific injury because ACA burdened his performance of duties as an elected official. ${ }^{234}$ The court did not allow Kinder to change postures for the purpose of raising those claims. ${ }^{235}$ Therefore, hewing to the rule that a plaintiff must assert his own legal rights and interests, not those of third parties, the court denied standing to all the plaintiffs on claims alleging burdens on the state. ${ }^{236}$ Citing an Eighth Circuit opinion, United States v. Hacker, ${ }^{237}$ the Missouri District Court reasoned precisely the opposite of Justice Kennedy in Bond, to wit: "[A] private party does not have standing to assert that the federal government is encroaching on state sovereignty in violation of the Tenth Amendment absent the involvement of a state or its instrumentalities." 238 The court observed that the State of Missouri might have standing to assert those claims, but individual residents of the state do not. ${ }^{239}$

The plaintiffs further challenged the requirement that the State of Missouri, as an employer, would have to provide health benefits to employees. ${ }^{240}$ On that count, Kinder asserted standing as a state employee who recruited and hired employees, suggesting that the cost of insurance would affect his ability to perform his duties. ${ }^{241}$ The court concluded that Kinder could not claim any injury because his term ends in January 2013 , a year before the employer responsibility provision takes effect. ${ }^{242}$ Moreover, he did not assert that he would be "injured," but merely "affected," by the requirement to offer health insurance to state employees. ${ }^{243}$ The other individual plaintiffs claimed injury because the employer health plan requirement would increase costs to Missouri taxpayers. ${ }^{244}$ The court deemed that assertion too speculative and again contrary to the cited language in Hacker. ${ }^{245}$

The plaintiffs' various challenges to the individual mandate also failed to satisfy the constitutional minimum for standing because the plaintiffs did not allege any injury. ${ }^{246}$ For example, the twenty-one-year-old plaintiff incorrectly asserted that she would be subject to the penalty because she desired to purchase only catastrophic health insurance. ${ }^{247} \mathrm{ACA}$, however, expressly provides that very option for individuals under the age of thirty. ${ }^{248}$ The court deemed other assertions too speculative as plaintiffs failed to allege that they, in fact, would not purchase health insurance in 2014 , only that they would be subject to the ACA's penalty if they did not. ${ }^{249}$ The plaintiffs' reliance on rights that the Missouri HCFA ostensibly

${ }^{234} \mathrm{Id}$.

${ }^{235} \mathrm{Id}$.

${ }^{236}$ Id. (citing Valley Forge Christian Coll. v. Ams. United for Separation of Church \& State, Inc., 454 U.S. 464, 474 (1982)).

${ }^{237} 565$ F.3d 522 (8th Cir. 2009).

${ }^{238}$ Kinder, 2011 WL 1576721, at *4 (quoting Hacker, 565 F.3d at 526).

${ }^{239} \mathrm{Id}$.

240 Id. at $* 5$.

${ }^{241} I d$.

${ }^{242} I d$.

${ }^{243} \mathrm{Id}$.

${ }^{244} \mathrm{Id}$.

${ }^{245} \mathrm{Id}$; ; see infra notes $249-50$ and accompanying text.

${ }^{246}$ Kinder, 2011 WL 1576721, at *6.

${ }^{247}$ Id.

${ }^{248}$ Id.; see 26 U.S.C.A. $\S 5000 \mathrm{~A}(\mathrm{e})$ (West 2012).

${ }^{249}$ Kinder, 2011 WL 1576721, at *6. 
protected ${ }^{250}$ was also unavailing as they did not allege that they did not currently participate in the healthcare system or maintain health insurance. ${ }^{251}$

Finally, plaintiffs vaguely alleged that section 4003 of the ACA, empowering the Preventative Services Task Force to conduct cost-effectiveness research, violated their liberty interests in making personal medical decisions and interfered with the physician-patient relationship. ${ }^{252}$ The court carefully explained that section 4003 had no such effect and, moreover, that the plaintiffs failed to allege any actual injury resulting from section 4003's operation. ${ }^{253}$ After reviewing additional ripeness and mootness arguments, the court granted the defendants' motion to dismiss all counts. $^{254}$

\section{Shreeve v. Obama ${ }^{255}$}

In a would-be class action, Anthony Shreeve and a group of 25,000 other individuals and entities sought declaratory, injunctive, and monetary relief, alleging "direct and immediate" violations of their constitutional rights. ${ }^{256}$ Specifically, they asserted that the defendants, Barak Obama, Nancy Pelosi, Harry Reid, and the United States, exceeded the scope of their constitutional authority, violated the Tenth Amendment, and breached their oaths of office to protect and defend the Constitution. The plaintiffs did not claim any injury by operation of the individual mandate, such as that they would be compelled to purchase health insurance, or required to rearrange their financial affairs or prepare presently for the individual mandate's future effective date. ${ }^{257}$ Accordingly, the plaintiffs failed to show any concrete injury or personal stake in the controversy. Their claims were squarely within the prohibition on generalized grievances about government, "claiming only harm to his and every citizen's interest in proper application of the Constitution and laws." ${ }^{258}$ The court, accordingly, dismissed all the claims. ${ }^{259}$

\section{Bellow v. Department of Health and Human Services ${ }^{260}$}

The case involved a lone pro se plaintiff challenging the constitutionality of the ACA. $^{261}$ The Eastern District of Texas construed the plaintiff's vague complaint as challenging the individual mandate and then looked to other courts' ACA standing decisions. ${ }^{262}$ Magistrate Judge Keith Giblin concluded that Bellow's allegations were more like the Shreeve plaintiffs' generalized grievances about government than the Florida, Thomas More, Seven-Sky, and Goudy-Bachman plaintiffs' allegations of particular financial and business rearrangements necessitated by the individual

\footnotetext{
${ }^{250}$ Missouri Health Care Freedom Act, Mo. ANN. STAT. $\$ 1.330(1)$ (West 2012) ("No law or rule shall compel, directly or indirectly, any person, employer, or health care provider to participate in any health care system.").

${ }^{251}$ Kinder, 2011 WL 1576721 , at*7.

${ }^{252} I$ Id.

${ }^{253}$ Id. at $* 7-8$.

${ }^{254} I d$. at $* 8-10$

${ }^{255} 1: 10-C V-71,2010$ WL 4628177 (E.D. Tenn. Nov. 4, 2010).

${ }^{256} \mathrm{Id}$. at $* 1-* 3$.

${ }^{257}$ Id. at $* 4$.

${ }^{258} I d$. at $* 3$ (citing Lujan v. Defenders of Wildlife, 504 U.S. 555, 573-74 (1992)).

${ }^{259}$ Id. at $* 7$.

${ }^{260}$ No. 1:10-CV-165, 2011 WL 2470456 (E.D. Tex. June 18, 2011).

$261 \mathrm{Id}$. at ${ }^{*} 1$.

${ }^{262}$ Id. at $* 6$
} 
mandate. ${ }^{263}$ Bellow's alleged injury that he would be forced to pay for insurance or face a penalty in 2014 was "purely hypothetical" and not immediate. ${ }^{264}$ Accordingly, Judge Giblin recommended that the case be dismissed. ${ }^{265}$

\section{Peterson v. United States ${ }^{266}$}

Peterson presented the novel question whether a Medicare recipient has standing to challenge the ACA and the individual mandate. ${ }^{267}$ The New Hampshire District Court noted that, as a Medicare recipient, "Peterson will not have to incur any financial burdens, or indeed do anything at all, to satisfy the mandate. The federal government will satisfy it for him." ${ }^{, 268}$ Accordingly, the court held that he lacked standing to challenge the mandate on any of his asserted grounds. ${ }^{269}$

Peterson further alleged that he was injured by the ACA's mere passage, which caused his Medicare supplemental insurance premiums to rise, ${ }^{270}$ and that the Act might cause him to suffer loss of Medicare benefits in future years. ${ }^{271}$ The court deemed both arguments too speculative and vague. ${ }^{272}$ With regard to the supplemental insurance premium claim, the court noted that the third-party insurer was not before the court, and thus that Peterson's claim would not be redressed in the lawsuit. ${ }^{273}$ Accordingly, the case was dismissed. ${ }^{274}$

\section{RESOLVING THE ACA STANDING PARADOX}

The ACA case before the Supreme Court, and lower court decisions, leave an unresolved standing paradox. Individuals may sue to protect states' interests, but states may not sue to protect individuals'-or, apparently, their own-interests. That posture may be the result of strategic error by plaintiff-states or rigid application of standing doctrine by the courts. In either case, the result does not comport with the purposes underlying standing in ensuring that the parties with real interests in resolution of the issues are before the court and maintaining separation of powers. As long as states meet the same constitutional requirements for standing as individuals, they should have the same claim to judicial review of federal laws, especially when the states' challenge is based on structural federalism grounds.

The core legal question before the Supreme Court in the ACA litigation is the scope of federal enumerated powers vis-à-vis states' reserved powers. ${ }^{275}$ Because of the weakness of personal autonomy or economic liberties claims, private individuals, employers, and associations challenge the individual mandate as exceeding federal

${ }^{263}$ Id. at $* 11$.

264 Id. at $* 12$.

${ }^{265} I d$. at $* 13$.

${ }^{266} 774$ F. Supp. 2d 418 (D.N.H. 2011).

${ }^{267} \mathrm{Id}$. at 420 .

${ }^{268}$ Id. at 424.

${ }^{269} \mathrm{Id}$.

${ }^{270} \mathrm{Id}$.

${ }^{271} I d$. at 425 .

${ }^{272}$ Id. at 424-25.

${ }^{273} \mathrm{Id}$. at 424 .

${ }^{274}$ Id. at 426.

${ }^{275}$ Dep't of Health \& Human Servs. v. Florida, 132 S. Ct. 604 (2011) (No. 11-398) (mem.) (argued Mar. 26-27, 2012) (granting certiorari on the question of whether Congress had the power to enact the minimum coverage provision). 
commerce and spending powers. ${ }^{276}$ Lower courts readily exercised jurisdiction over those claims as long as the private plaintiffs alleged concrete, particularized harm in having to prepare for the future effective date of the ACA's requirements. States' interests in challenging the alleged expansion of federal power is arguably even more direct than individuals' interest in safeguarding individual rights through the conduit of structural limits on federal power. ${ }^{277}$ Yet lower courts were reluctant to recognize state standing to challenge the individual mandate on the same structural grounds.

Individual, employer, and association challenges to ACA are postured as defenses to potential government enforcement actions. Those plaintiffs allege that the federal law itself is unconstitutional and therefore cannot be applied against them. For the most part, lower courts generously accepted individual plaintiffs' alleged injuries based on present-day financial impact or change in position in anticipation of the individual mandate's future effective date. The courts rejected as too speculative the government defendants' suggestions that the plaintiffs might avoid the mandate by death, emigration, employment, or exemption. ${ }^{278}$ Injury resulting from the individual mandate is easy to allege; any prudent manager of family or business finances can point to some forgone purchase or change in savings habits in anticipation of future expenses. ${ }^{279}$ Indeed, a group of plaintiffs who were initially dismissed for lack of standing were allowed to amend their pleadings. They filed identical amended complaints, which salvaged their case:

In Plaintiffs' Second Amended Petition, they alleged that they are currently "rearranging [their] financial affairs differently than [they] otherwise would in order to prepare for the January 1, 2014, implementation of the Individual Mandate." Each Plaintiff alleged that "he is making decisions to forego certain spending today, so that he will have the funds to pay for the penalties associated with his noncompliance and the associated legal costs of defending himself for noncompliance when the Individual Mandate begins implementation on January 1, 2014." Finally, each Plaintiff alleged that he has made "significant and costly changes in ... personal financial planning, necessitating significant lifestyle changes and extensive reorganization of ... personal and financial affairs." 280

Rote recitations of personal, concrete injury seem sufficient for Article III standing purposes, ${ }^{281}$ even though they do not meaningfully distinguish the individual ACA

\footnotetext{
${ }^{276}$ See supra Part II (describing individual rights claims).

${ }^{277}$ See supra Part II (describing two ways in which structural federalism could be seen to protect individual rights).

${ }^{278}$ See, e.g., Thomas More Law Ctr. v. Obama, 651 F.3d 529, 537 (6th Cir. 2011 ), petition for cert. filed, (U.S. July 26, 2011) (No. 11-117).

${ }_{279}$ See, e.g., Gaudy-Bauchman v. U.S. Dep't of Health \& Human Servs., 764 F. Supp. 2d 684, 670-71 (M.D. Pa. 2011) (regarding decision not to purchase a new car, payments for which plaintiffs could afford absent the individual mandate); Liberty Univ., Inc. v. Geithner, 753 F. Supp. 2d 611, 622-23 (W.D. Va. 2010), vacated, No. 10-2347, 2011 WL 3962915 (4th Cir. Sept. 8, 2011 ), petition for cert filed, 80 U.S.L.W. 3240 (U.S. Oct. 7, 2011) (No. 11-438) (describing large employer's allegations).

${ }^{280}$ See Bryant v. Holder, 809 F. Supp. 2d 563, 566-67 (S.D. Miss. 2011) (recognizing sufficient injury-in-fact to support standing).

${ }^{281}$ Americans who already have health insurance that complies with the individual mandate may not have standing to challenge the individual mandate. See, e.g., Baldwin v. Sebelius, 654 F.3d 877 , 879 (9th Cir. 2011) (plaintiff failed to allege that he lacked health insurance presently and would not
} 
plaintiffs from any other American generally opposed to the mandate to purchase health insurance, specifically, or federal health reform, generally. ${ }^{282}$ As long as the claimed injury is real and concrete, and more than a generalized grievance about the government's proper application of the law, ${ }^{283}$ the court is not deprived of jurisdiction just because the injury is widely shared. ${ }^{284}$

Without disrupting those and other settled principles of standing, courts could similarly recognize state standing to challenge the individual mandate. States cannot sue merely as nominal plaintiffs to protect their inhabitants from unconstitutional federal laws. ${ }^{285}$ Nor should states be allowed to legislate around the Mellon doctrine simply by passing a state statute and then claiming a sovereign interest in enforcing it. ${ }^{286}$ To invoke Article III jurisdiction, states must assert their own rights and interests. It is not clear whether states' general interest in protecting the domain of reserved powers from erosion by expanded federal powers is sufficient for standing purposes. ${ }^{287}$ It is clear, however, that individuals must allege injury-in-fact resulting from an allegedly unconstitutional exercise of federal power in order to bring a Tenth Amendment challenge. ${ }^{288}$ If states make similar allegations, at least in those

have it in 2014); Peterson v. United States, 774 F. Supp. 2d 418 (D.N.H. 2011) (rejecting claim by Medicare beneficiary). But see Seven-Sky v. Holder, 766 F. Supp. 2d 16, 23 (D.D.C. 2011), hearing en banc denied sub nom. Seven-Sky v. Holder, 2011 WL 1113489 (D.C. Cir. Mar 17, 2011), aff'd, 661 F.3d 1 (D.C. Cir. 2011 ), petition for cert. filed, 80 U.S.L.W. 3359 (U.S. Nov. 30, 2011 ) (No. 11-679) (considering Medicare-eligible plaintiff's suggestion that she would refuse to enroll in Medicare); Bryant, 809 F. Supp. 2d at 566-67 (alleging that ACA requires individuals not only to obtain, but also to maintain, health insurance).

${ }^{282}$ According to recent polls, close to half of Americans oppose ACA. See KAISER HEALTH TRACKING POLL, KAISER FAM. FOUND. (2011), http://www.kff.org/kaiserpolls/upload/8265-F.pdf (reporting forty-three percent unfavorable and forty-one percent favorable opinions on the federal health reform law).

${ }^{283}$ Lujan v. Defenders of Wildlife, 504 U.S. 555, 573-74 (1992).

${ }^{284}$ See FEC v. Atkins, 524 U.S. 11, 24-25 (1998); Pub. Citizen v. U.S. Dep't of Justice, 491 U.S 440, 449-50 (1989).

${ }^{285}$ Massachusetts v. Mellon, 262 U.S. 447, 485 (1923).

${ }^{286}$ Id.; Virginia ex rel. Cuccinelli v. Sebelius, 656 F.3d 253, 269 (4th Cir. 2011), petition for cert. filed 80 U.S.L.W. 3221 (U.S. Sept. 30, 2011) (No. 11-420); see Stephen I. Vladeck, States' Rights and State Standing, 46 UNIV. RICH. L. REV. 845, 872-74 (2012) (providing normative reasons for rejecting standing on the allegations in Virginia).

${ }^{287}$ See Bryant v. Holder, 809 F. Supp. 2d 563, 569 n.l (S.D. Miss. 2011) (noting that public official asserting state sovereign interest would still have to show his own injury-in-fact); Kinder $v$ Geithner, No. 1:10-CV-101-RWS, 2011 WL 1576721, at *4 (E.D. Mo. Apr. 26, 2011) (suggesting in dicta that a state might bring a Tenth Amendment challenge, although denying standing to individuals or public officials on that ground). Other opinions, not on standing, equivocate on the enforceability of the Tenth Amendment as a discrete limit on federal powers. See, e.g., United States v. Comstock, 130 S. Ct. 1949, 1967 (2010) (Kennedy, J., concurring) (urging the Court to extend Tenth Amendment limits on spending power, similar to commerce power); New York v. United States, 505 U.S. 144, 177-78 (1992) (recognizing that the Tenth Amendment prohibits Congress from compelling state governments to regulate pursuant to federal directive but allows Congress to regulate matters directly and preempt contrary state laws); South Carolina v. Dole, 483 U.S. 203, 210 (1987) (declining to recognize general Tenth Amendment limit on federal spending power); Garcia v. San Antonio Metro. Transit Auth., 469 U.S. 528, 570 (1985) (Powell, J., dissenting) (admonishing Court for failing to give judicial enforcement to the Tenth Amendment); United States v. Darby, 312 U.S. 100, 124 (1941) (concluding that the Tenth Amendment "states but a truism that all is retained which has not been surrendered").

${ }^{288}$ See Bond v. United States, 131 S. Ct. 2355 (2011) (threat of sanctions under federal law sufficed for injury-in-fact, allowing individual standing to challenge statute on Tenth Amendment grounds); Purpura v. Obama, 446 Fed. Appx. 496, $497-98$ (3d Cir. 2011), cert. denied 132 S. Ct. 1037 (2012), reh'g denied, No. 11-7275, 2012 WL 538800 (U.S. Feb. 21, 2012) (distinguishing Bond 
narrow cases, there seems little harm in allowing them standing to vindicate structural limits on federal power. ${ }^{289}$

The states' ACA challenge to the individual mandate may not squarely fit recognized categories of state standing-proprietary, sovereign, and quasi-sovereign interests-but simple application of the injury-in-fact requirement supports the cognizability of their claims. First consider states' ACA claims under the recognized categories: states do not assert any proprietary interest, other than one state official's attempt to challenge the ACA employer responsibility requirements. ${ }^{290}$ Even though a state employer may have an interest in that provision, the official failed to allege that he was "injured," as opposed to merely "affected," by the requirement or that he would still be in office as a state employer in $2014 .{ }^{291}$ Accordingly, the claim was dismissed for failing to allege concrete, particularized injury.

With respect to sovereign interest standing, Virginia and other states asserted their interest in enforcing state HCFAs. Two district courts agreed that the existence of a validly enacted state law triggered the states' attorney generals' "duty . . . to defend the law and the associated sovereign power to enact it. ${ }^{, 292}$ In one case, that reasoning was squarely rejected on appeal. ${ }^{293}$ The Fourth Circuit correctly admonished Virginia's attempt to legislate its way around the clear prohibition on parens patriae standing simply by passing a state law purporting to shield state residents from federal law. ${ }^{294}$ Just as states cannot litigate individual rights claims of their inhabitants, ${ }^{295}$ states cannot enact laws providing that federal law does not

plaintiff from ACA plaintiffs because former challenged current incarceration, which would be redressed my favorable judicial decision).

${ }^{289}$ My suggestion for state standing based on injury-in-fact respects Professor Vladeck's normative concerns about sovereign interest standing in the Virginia case, including allowing a conflict between state and federal laws to suffice for injury-in-fact, inviting an end-run around principles of judicial restraint through state nullification laws, and expanding state standing at the expense of individual standing. See Vladeck, supra note 286, at 872-73.

${ }^{290}$ Kinder, 2011 WL 1576721 , at *5.

291 Id.

${ }^{292}$ Virginia ex rel. Cuccinelli v. Sebelius, 702 F. Supp. 2d 598, 605-06 (E.D. Va. 2010), rev'd, 656 F.3d 253 (4th Cir. 2011), petition for cert. filed, 80 U.S.L.W. 3221 (U.S. Sept. 30, 2011 ) (No. 11 420) (noting that the "mere existence of the lawfully-enacted statute is sufficient to trigger the duty of the Attomey General of Virginia to defend the law and the associated sovereign power to enact it"); Florida ex rel. Bondi v. U.S. Dep't of Health \& Human Servs., 780 F. Supp. 2d 1256, 1272 (N.D. Fla. 2011), order clarified, 780 F. Supp. 2d 1307 (N.D. Fla. 2011), aff'd in part, rev'd in part sub nom., Florida ex rel. Att'y Gen. v. U.S. Dep't of Health \& Human Servs., 648 F.3d 1235 (11 th Cir. 2011), cert. granted sub nom. Nat'l Fed'n of Indep. Bus. v. Sebelius, 132 S. Ct. 603 (2011) (mem.), and cert. granted sub nom. Dep't of Health \& Human Servs. v. Florida, 132 S. Ct. 604 (2011) (mem.), argued, No. 11-398 (Mar. 26-27, 2012), and cert. granted in part sub nom., Florida v. Dep't of Health \& Human Servs., 132 S. Ct. 604 (2011) (mem.), argued, No. 11-400 (Mar. 28, 2012) (quoting Virginia, 702 F. Supp. $2 d$ at $605-06$, and agreeing with Judge Hudson's reasoning with respect to Idaho and Utah, two states that had enacted HCFAs); see Katherine Mims Crocker, Securing Sovereign State Standing, 97 VA. L. REV. 2051, 2094-95 (2011) (discussing the Virginia District Court opinion as an example of sovereign interest standing).

${ }^{293}$ Virginia ex rel. Cuccinelli, 656 F.3d at 272 . The Eleventh Circuit did not have to decide the issue of state standing to challenge the individual mandate, including this asserted ground. See Florida ex rel. Att'y Gen., 648 F.3d at 1243.

${ }^{294}$ Virginia ex rel. Cuccinelli, 656 F.3d at 271. But see generally Kenneth T. Cuccinelli et al., State Sovereign Standing: Often Overlooked, But Not Forgotten, 64 STAN. L. REV. 89, 90 (2012) (Virginia's Attorney General "explain[ing] why those who question Virginia's standing are fundamentally incorrect").

${ }^{295}$ See South Carolina v. Katzenbach, 383 U.S. 301, 323-24 (1966) (disallowing the state to challenge Federal Voting Rights Act on individual rights grounds while recognizing constitutionally protected sovereign interest in state control of voting qualifications) 
apply to individuals within their borders and then claim injury to their sovereign interest in enforcing otherwise clearly preempted state law. ${ }^{296}$

Sovereign-interest standing, however, does support state challenges to Medicaid expansion, if not the individual mandate. The ACA's Medicaid conditional funding requirements operate directly on states whereas the individual mandate operates most squarely on individuals. ${ }^{297}$ Nevertheless, states could plausibly assert standing to challenge the individual mandate related to their clear standing to challenge Medicaid expansion. Quite conceivably, enforcement of the individual mandate and availability of health insurance subsidies through state exchanges will spur more citizens to apply for coverage. ${ }^{298}$ Those incentives, combined with the ACA's broader Medicaid eligibility rules, will likely result in many more applicants qualifying for Medicaid than before ACA. ${ }^{299}$ As a result, states' burden of covering both previously and newly eligible beneficiaries will be greater than under Medicaid expansion alone. ${ }^{300}$ The Eleventh Circuit did not squarely decide the Medicaid bootstrap argument because the individual and association plaintiffs otherwise had standing to challenge the individual mandate. ${ }^{301}$

As to the third category of state standing, Virginia expressly disavowed reliance on quasi-sovereign-interest standing, ${ }^{302}$ although a plausible argument could be made on that basis as well. Supreme Court precedent on quasi-sovereign interest standing is scant, but the Court has recognized states' judicially cognizable interest in the health and well-being of their inhabitants when the alleged risk otherwise is too broad and vague to meet the requirements of individual standing. ${ }^{303}$ The ACA individual mandate arguably does not present a broad, vague risk of harm, akin to greenhouse gas emissions, ${ }^{304}$ or full and equal participation in a federal statutory scheme. ${ }^{305}$ Indeed, the very ease with which individual ACA plaintiffs alleged

${ }^{296}$ Compare, for example, "trigger laws" that ban abortion within state borders and purport to take effect as soon as federal law permits. See William Michael Treanor \& Gene B. Sperling, Prospective Overruling and the Revival of "Unconstitutional" Statutes, 93 COLUM. L. REV. 1902 (1993); Matthew Berns, Note, Trigger Laws, 97 GEo. L.J. 1639 (2009). Those laws have not and should not be interpreted as allowing states' standing to challenge federal abortion policy.

${ }^{297}$ See Woolhandler \& Collins, supra note 1, at 508-09 (suggesting that "courts should allow states standing where states contest the application of federal regulatory burdens directly on states" and citing examples, such as wage-hour laws and pollution control).

${ }^{298}$ See Edmund Haislmaier \& Brian Blase, Obamacare: Impact on States, 2433 BACKGROUNDER 1, 2 (2010), available at http://thf_media.s3 amazonaws.com/2010/pdf/bg2433.pdf.

${ }^{299} \mathrm{Id}$.

${ }^{300}$ See Florida ex rel. Att'y Gen. v. U.S. Dep't of Health \& Human Servs., 648 F.3d 1235, 1243 (11th Cir. 2011), cert. granted sub nom. Nat'l Fed'n of Indep. Bus. v. Sebelius, 132 S. Ct. 603 (2011) (mem.), and cert. granted, 132 S. Ct. 604 (2011) (No. 11-398) (mem.) (argued Mar. 26-27, 2012), and cert. granted in part, 132 S. Ct. 604 (2011) (No. 11-400) (mem.) (argued Mar. 28, 2012) (state plaintiffs alleged standing, in part, "because increased enrollment in Medicaid spurred by the individual mandate will cost the states millions of dollars in additional Medicaid funding").

${ }^{301}$ Id.

${ }^{302}$ Virginia ex rel. Cuccinelli v. Sebelius, 702 F. Supp. 2d 598, 603 (E.D. Va. 2010), rev'd, 656 F.3d 253 (4th Cir. 2011), petition for cert. filed, 80 U.S.L.W. 3221 (U.S. Sept. 30, 2011 ) (No. 11 420).

${ }^{303}$ See Massachusetts v. Envtl. Prot. Agency, 549 U.S. 497, 514-15 (2007) (noting intervention of states and local governments, including the Commonwealth of Massachusetts, which, at least, had standing, even if individual plaintiff' ' injuries were not sufficiently particularized).

${ }^{304}$ Massachusetts, 549 U.S. at 515

${ }^{305}$ Alfred L. Snapp \& Son, Inc. v. Puerto Rico, 458 U.S. 592, 602 (1982). 
concrete and particularized injury ${ }^{306}$ undermines the diffuse injury rationale for quasi-sovereign interest state standing.

The contours of state standing doctrine announced in the Court's recent precedent, Massachusetts v. Environmental Protection Agency, are not entirely clear. ${ }^{307}$ But the decision does not rely solely on quasi-sovereign interests. Massachusetts also asserted a proprietary interest as a landowner in protecting its ocean shores from rising sea levels due to global warming. ${ }^{308}$ Although drawing on parens patriae and quasi-sovereign interest case-law, ${ }^{309}$ the Court concluded: "That Massachusetts does in fact own a great deal of the 'territory alleged to be affected' only reinforces the conclusion that its stake in the outcome of this case is sufficiently concrete to warrant the exercise of federal judicial power." ${ }^{310}$ The nuances of Massachusetts v. Environmental Protection Agency's holding are not necessary to recognize state standing in the ACA litigation. The Court's "special solicitude"311 to state interests in challenging federal laws should at least encompass standing parity, if not a "special pass into court," 312 to states. As long as states allege concrete, particularized injury to their own interests as a result of the individual mandate they should be allowed access to federal courts.

The most straightforward analysis of state standing in the ACA litigation is to apply the well-established injury-in-fact requirement, the constitutional minimum that all plaintiffs must meet. Even under quasi-sovereign interest standing, states still must show real interest of their own in the litigation, ${ }^{313}$ which the ACA plaintiffstates did not. ${ }^{314}$ But I contend that they could have. The Virginia District Court, in rejecting a ripeness challenge to the Commonwealth's claim, acknowledged that the individual mandate does not take effect until 2014 , but "that does not mean that its effects will not be felt by the Commonwealth in the near future." 315 Judge Hudson further observed that individuals, insurance companies, and employers have to take steps to ensure that their current health plans comply with ACA or evaluate and contract for insurance coverage in the near future. ${ }^{316}$ More to the point of state standing, and " $[\mathrm{m}]$ ore importantly, the Commonwealth must revamp its health care program to ensure compliance with the enactment's provisions, particularly with respect to Medicaid. This process will entail more than simple fine tuning."317

Further allegations, along the lines of the Medicaid bootstrap argument, ${ }^{318}$ buttressed by description of particular planning efforts and budget compromises that

${ }^{306}$ See supra Part II (discussing individual plaintiffs' factual allegations).

${ }^{307}$ See Schapiro, supra note 1, at $998 \mathrm{n} .111$ (citing scholarly commentary).

${ }^{308}$ Massachusetts, 549 U.S. at 522.

${ }^{309} \mathrm{Id}$. at $520 \mathrm{n} .17$.

${ }^{310} \mathrm{Id}$. at 519

${ }^{311}$ Id. at 520.

${ }^{312}$ Schapiro, supra note 1 , at 1005.

${ }^{313}$ Alfred L. Snapp \& Son, Inc. v. Puerto Rico, 458 U.S. 592, 600 (1982).

314 See Vladeck, supra note 286, at 870 (asserting that "there is no federal statute or constitutional provision that in any way creates or otherwise recognizes a distinct injury that Virginia will suffer as a state as a result of the ACA's minimum essential coverage provision").

${ }^{315}$ Virginia ex rel. Cuccinelli v. Sebelius, 702 F. Supp. 2d 598, 608 (E.D. Va. 2010), rev'd, 656 F.3d 253 (4th Cir. 2011), petition for cert. filed, 80 U.S.L.W. 3221 (U.S. Sept. 30, 2011) (No. 11 420).

${ }^{316} \mathrm{Id}$.

${ }^{317} I d$.

${ }^{318}$ See Kevin C. Walsh, The Ghost that Slayed the Mandate, 64 STAN. L. REV. 55, 73-75 (2012) (rejecting the Medicaid bootstrap argument for standing because any state injury is merely "indirect," arising by virtue of private citizens' reactions to the individual mandate by enrolling in Medicaid). 
states are currently undertaking in anticipation of the 2014 effective date ${ }^{319}$ should be sufficient for Article III standing purposes. In overturning Judge Hudson's decision on the Commonwealth's standing, the Fourth Circuit acknowledged that factors such as "a taxpayer's current possession of health insurance, current or planned future consumption of health care, or related voluntary action" would provide a sufficiently concrete factual context to support standing. ${ }^{320}$ But the court did not consider similar future regulation of and present-day planning, saving, and action by the Commonwealth as providing "concrete adverseness" for state standing. ${ }^{32}$

The Commonwealth perhaps did not adequately allege, and the Fourth Circuit certainly did not consider, similar future regulation of and present-day planning, saving, and action as providing "concrete adverseness" for state standing. In addition to the woodwork effects of Medicaid, Virginia and other states could have more clearly alleged present-day injury in having to adjust state budgets to prepare to implement Medicaid expansion and other changes compelled by the law, survey state insurance laws for compliance with ACA, and decide whether to cooperate with the federal government in establishing state-based health insurance exchanges to facilitate the individual mandate. The point is that these ACA provisions operate directly on states, requiring present-day fiscal and administrative preparation to effectuate the individual mandate.

With respect to private plaintiffs, lower courts readily recognized their standing to challenge the minimum essential coverage requirement that takes effect in 2014 as long as they alleged some present-day financial impact or change in personal or spending habits in anticipation of that date. States, it seems, could just as easily allege concrete and particularized planning and budgetary impacts deriving from the individual mandate. States have a real stake-arguably an even greater stake than individuals-in resolving questions over the relative scope of federal and state powers. ${ }^{322}$ If the constitutional minimum requirements for standing can be trusted to preserve the adversarial process and separation of powers in cases involving private litigants, those limits should likewise suffice for cases involving state litigants.

\footnotetext{
${ }^{319}$ See, e.g., Diane Justice, ImPlementing the Affordable Care Act: New Options for

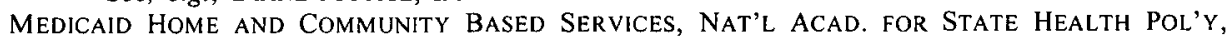
(2010), available at http:/www.nashp.org/sites/default/files/LTSS_SCAN-FINAL-9-29-10.PDF (observing that "[s]tates have significant roles in implementing practically all aspects of the Affordable Care Act"); RACHEL MORGAN, THE 2011 STATE LEGISLATORS' CHECK LiST FOR HEALTH REFORM IMPLEMENTATION, NAT'L CONFERENCE OF STATE LEgiSLATURES (2011), available at http:/www.ncsl.org/documents/health/State_Legislators_Checkdec20.pdf (detailing each provision of ACA calling for state response, including many tied to the individual mandate).

${ }^{320}$ See Virginia ex rel. Cuccinelli, 656 F.3d at $272-73$ (reversing district court's standing decision).

${ }^{321}$ Id. (citing Comite de Apoyo a los Trabajadores Agricolas v. U.S. Dep't of Labor, 995 F.2d 510,513 (4th Cir. 1993))

${ }^{322}$ See, e.g., Saikrishna B. Prakash \& John C. Yoo, The Puzzling Persistence of Process-Based Federalism Theories, 79 TEX. L. REV. 1459, 1462 (2001) (arguing that process federalism does not adequately protect states' interests and thus the federal courts must play an active role); Ernest A Young, Making Federalism Doctrine: Fidelity, Institutional Competence, and Compensating Adjustments, 46 WM. \& MARY L. REV. 1733, 1815-44 (2005) (arguing that the federal courts have a primary role to play in questions of federalism doctrine)
} 


\section{CONCLUSION}

The central issue in the ACA litigation is the constitutionality of the minimum essential coverage requirement, better known as the individual mandate. Both individuals, who will be subject to the requirement and associated sanctions for noncompliance, and states, which play a central role in implementing the individual mandate, challenge its constitutionality. Because individuals cannot assert plausible due process objections to the requirement to purchase health insurance, they instead argue that Congress has exceeded the scope of its enumerated powers by enacting such a law. That issue, regarding the federal structure of government, is particularly and directly salient to states. Lower courts readily recognized private plaintiffs' standing to challenge the individual mandate on structural grounds but were less willing to allow states to bring similar claims. This Article argues for states' standing parity. 
APPENDIX A: CASES RECOGNIZING STANDING

\begin{tabular}{|c|c|c|c|c|}
\hline Case Name & Court & Plaintiff & $\begin{array}{c}\text { ACA Provision } \\
\text { Challenged }\end{array}$ & Merits Decision \\
\hline $\begin{array}{l}\text { Florida v. } \\
\text { HHS }\end{array}$ & 11 th Cir. & $\begin{array}{l}\text { Individuals; } \\
\text { Association } \\
\text { States }\end{array}$ & $\begin{array}{l}\text { Individual } \\
\text { Mandate } \\
\text { Medicaid }\end{array}$ & $\begin{array}{l}\text { Unconstitutional } \\
\text { Constitutional }\end{array}$ \\
\hline $\begin{array}{l}\text { Thomas } \\
\text { More v. } \\
\text { Obama }\end{array}$ & 6th Cir. & $\begin{array}{l}\text { Individuals; } \\
\text { Association }\end{array}$ & $\begin{array}{l}\text { Individual } \\
\text { Mandate }\end{array}$ & Constitutional \\
\hline $\begin{array}{l}\text { Liberty } \\
\text { Univ. v. } \\
\text { Geithner }\end{array}$ & 4th Cir. & $\begin{array}{l}\text { Individuals; } \\
\text { Employer; } \\
\text { Public } \\
\text { Officials; } \\
\text { Physician }\end{array}$ & $\begin{array}{l}\text { Individual } \\
\text { Mandate; } \\
\text { Employer } \\
\text { Responsibility }\end{array}$ & $\begin{array}{l}\text { Barred by TAIA } \\
\text { (No standing for } \\
\text { public officials or } \\
\text { physician) }\end{array}$ \\
\hline $\begin{array}{l}\text { Seven-Sky } \\
\text { v. Holder }\end{array}$ & D.C. Cir. & $\begin{array}{l}\text { Individuals } \\
\text { (including } \\
\text { Medicare- } \\
\text { eligible) }\end{array}$ & $\begin{array}{l}\text { Individual } \\
\text { Mandate }\end{array}$ & $\begin{array}{l}\text { Constitutional } \\
\text { (Strong dissent on } \\
\text { TAIA) }\end{array}$ \\
\hline $\begin{array}{l}\text { Goudy- } \\
\text { Bachman v. } \\
\text { HHS }\end{array}$ & M.D. Pa. & Individuals & $\begin{array}{l}\text { Individual } \\
\text { Mandate }\end{array}$ & Unconstitutional \\
\hline
\end{tabular}

${ }^{323}$ Federal Tax Anti-Injunction Act, 26 U.S.C. $\$ 7421$ (a) (2006) (providing that "no suit for the purpose of restraining the assessment or collection of any tax shall be maintained in any court by any person"). 
APPENDIX B: CASES DENYING STANDING

\begin{tabular}{|c|c|c|c|c|}
\hline Case Name & Court & Plaintiff & $\begin{array}{c}\text { ACA Provision } \\
\text { Challenged }\end{array}$ & $\begin{array}{l}\text { Rationale for No } \\
\text { Standing }\end{array}$ \\
\hline $\begin{array}{l}\text { Virginia v. } \\
\text { Sebelius }\end{array}$ & 4th Cir. & State & $\begin{array}{l}\text { Individual } \\
\text { Mandate }\end{array}$ & $\begin{array}{l}\text { No parens patriae } \\
\text { standing }\end{array}$ \\
\hline $\begin{array}{l}\text { Baldwin v. } \\
\text { Sebelius }\end{array}$ & 9th Cir. & $\begin{array}{l}\text { Individuals; } \\
\text { Association; } \\
\text { Employers }\end{array}$ & $\begin{array}{l}\text { Individual } \\
\text { Mandate; } \\
\text { Employer } \\
\text { Responsibility }\end{array}$ & $\begin{array}{l}\text { No injury-in-fact; } \\
\text { employer too } \\
\text { small }\end{array}$ \\
\hline $\begin{array}{l}\text { New Jersey } \\
\text { Physicians } \\
\text { v. Obama }\end{array}$ & 3d Cir. & $\begin{array}{l}\text { Physician; } \\
\text { Association; } \\
\text { Patient }\end{array}$ & $\begin{array}{l}\text { Individual } \\
\text { Mandate; } \\
\text { Employer } \\
\text { Responsibility }\end{array}$ & No injury-in-fact \\
\hline $\begin{array}{l}\text { Pupura v. } \\
\text { Sebelius }\end{array}$ & 3d Cir. & Individuals & $\begin{array}{l}\text { Individual } \\
\text { Mandate }\end{array}$ & $\begin{array}{l}\text { No injury-in-fact, } \\
\text { even under } \\
\text { Bond }^{324}\end{array}$ \\
\hline $\begin{array}{l}\text { Bryant v. } \\
\text { Holder }\end{array}$ & $\begin{array}{l}\text { S.D. } \\
\text { Miss. }\end{array}$ & $\begin{array}{l}\text { Public } \\
\text { Officials; } \\
\text { Individuals }\end{array}$ & $\begin{array}{l}\text { Individual } \\
\text { Mandate }\end{array}$ & $\begin{array}{l}\text { No injury-in-fact } \\
\text { to public official, } \\
\text { even under Bond } \\
\text { (Individuals' } \\
\text { amended } \\
\text { complaints } \\
\text { sufficed) }\end{array}$ \\
\hline $\begin{array}{l}\text { Kinder v. } \\
\text { Geithner }\end{array}$ & E.D. Mo. & $\begin{array}{l}\text { Public } \\
\text { Official; } \\
\text { Public } \\
\text { Employer; } \\
\text { Individuals }\end{array}$ & $\begin{array}{l}\text { Individual } \\
\text { Mandate; } \\
\text { Employer } \\
\text { Responsibility }\end{array}$ & $\begin{array}{l}\text { No injury-in-fact; } \\
\text { no Tenth } \\
\text { Amendment } \\
\text { standing }\end{array}$ \\
\hline $\begin{array}{l}\text { Shreeve v. } \\
\text { Obama }\end{array}$ & $\begin{array}{l}\text { E.D. } \\
\text { Tenn. }\end{array}$ & $\begin{array}{l}25,000 \\
\text { Entities and } \\
\text { Individuals }\end{array}$ & $\begin{array}{l}\text { Individual } \\
\text { Mandate }\end{array}$ & No injury-in-fact \\
\hline $\begin{array}{l}\text { Bellow v. } \\
\text { HHS }\end{array}$ & E.D. Tex & Individual & $\begin{array}{l}\text { Individual } \\
\text { Mandate }\end{array}$ & No injury-in-fact \\
\hline $\begin{array}{l}\text { Peterson v. } \\
\text { United } \\
\text { States }\end{array}$ & D.N.H. & $\begin{array}{l}\text { Individual } \\
\text { (Medicare } \\
\text { Recipient) }\end{array}$ & $\begin{array}{l}\text { Individual } \\
\text { Mandate }\end{array}$ & $\begin{array}{l}\text { Medicare satisfies } \\
\text { mandate }\end{array}$ \\
\hline
\end{tabular}

${ }^{324}$ Bond v. United States, 131 S. Ct. 2355 (2011) (recognizing individual's standing to challenge indictment under federal statute on Tenth Amendment grounds). 